Bruin, S.R. de, Versnel, N., Lemmens, L.C., Molema, C.C.M., Schellevis, F.G., Nijpels, G., Baan C.A. Comprehensive care programs for patients with multiple chronic conditions: a systematic literature review. Health Policy: 2012, 107(2-3), 108-145

\begin{tabular}{|l|l|}
$\begin{array}{l}\text { Postprint } \\
\text { Version }\end{array}$ & 1.0 \\
\hline Journal website & http://www.sciencedirect.com/science/article/pii/S0168851012001649 \\
\hline Pubmed link & $\underline{\text { http://www.ncbi.nlm.nih.gov/pubmed/22884086 }}$ \\
\hline DOI & 10.1016/j.healthpol.2012.06.006
\end{tabular}

This is a NIVEL certified Post Print, more info at http://www.nivel.eu

\title{
Comprehensive care programs for patients with multiple chronic conditions: A systematic literature review
}

\author{
SimONE R. DE BRUIN ${ }^{A, *}$ NATHALIE VERSNEL ${ }^{\mathrm{B}, \mathrm{C}}$, LIDWIEN C. LEMMENS ${ }^{\mathrm{A}}$, CLAUdia C.M. \\ MOLEMA $^{\mathrm{A}}$, FRANÇOIS G. SCHELLEVIS ${ }^{\mathrm{B}, \mathrm{C}}$, GIEL NIJPELS ${ }^{\mathrm{B}}$, CAROLINE A. BAAN ${ }^{\mathrm{A}}$ \\ ${ }^{a}$ National Institute for Public Health and the Environment, Centre for Prevention and Health \\ Services Research, PO Box 1, 3720 BA Bilthoven, The Netherlands \\ ${ }^{b}$ Department of General Practice/EMGO+ Institute for Health and Care Research, VU \\ University Medical Center, v.d. Boechorststraat 7, 1081 BT Amsterdam, \\ The Netherlands \\ ${ }^{c}$ NIVEL, Netherlands Institute for Health Services Research, PO Box 1568, 3500 BN \\ Utrecht, The Netherlands
}

\begin{abstract}
A B S T R A C T
Objective: To provide insight into the characteristics of comprehensive care programs for patients with multiple chronic conditions and their impact on patients, informal caregivers, and professional caregivers.

Methods: Systematic literature search in multiple electronic databases for English language papers published between January 1995 and January 2011, supplemented by reference tracking and a manual search on the internet. Wagner's chronic care model (CCM) was used to define comprehensive care. After inclusion, the methodological quality of each study was assessed. A bestevidence synthesis was applied to draw conclusions.

Results: Forty-two publications were selected describing thirty-three studies evaluating twenty-eight comprehensive care programs for multimorbid patients. Programs varied in the target patient groups, implementation settings, number of included interventions, and number of CCM components to which these interventions related. Moderate evidence was found for a beneficial effect of comprehensive care on inpatient healthcare utilization and healthcare costs, health behavior of patients, perceived quality of care, and satisfaction of patients and caregivers. Insufficient evidence was found for a beneficial effect of comprehensive care on health-related quality of life in terms of mental functioning, medication use, and outpatient healthcare utilization and healthcare
\end{abstract}


Bruin, S.R. de, Versnel, N., Lemmens, L.C., Molema, C.C.M., Schellevis, F.G., Nijpels, G., Baan C.A. Comprehensive care programs for patients with multiple chronic conditions: a systematic literature review. Health Policy: 2012, 107(2-3), 108-145

costs. No evidence was found for a beneficial effect of comprehensive care on cognitive functioning, depressive symptoms, functional status, mortality, quality of life in terms of physical functioning, and caregiver burden.

Conclusion: Because of the heterogeneity of comprehensive care programs, it is as yet too early to draw firm conclusions regarding their effectiveness. More rigorous evaluation studies are necessary to determine what constitutes best care for the increasing number of people with multiple chronic conditions.

\section{INTRODUCTION}

Chronic diseases are the leading cause of disability and death in the western part of the world [1]. Over the coming years, the prevalence of chronic diseases is predicted to increase because of the rapid ageing of the world population and the greater longevity of people with chronic conditions [2-4]. An increasing proportion of the chronically ill is multimorbid [5,6]. The term "multimorbidity" refers to any cooccurrence of multiple chronic conditions within one person, and is to be distinguished from the term "co-morbidity" which refers to the combination of additional diseases beyond an index disorder [6-8]. The prevalence of multiple chronic conditions among individuals increases with age and is substantial among older adults [5]. In people over age 65 about $65 \%$ is multimorbid; in people over age 85 this proportion is about $85 \%[6,8,9]$.

Having multiple chronic conditions is associated with poor quality of life, disability, psychological distress, and an increased mortality risk $[6,10]$. The complex healthcare needs of most patients with multiple chronic conditions usually require the involvement of a large number of healthcare providers in the care process. Coordination of care is therefore difficult and healthcare providers often fail to address the integral healthcare demand, including psychosocial issues, of patients with multiple chronic conditions [8,11-13]. As a result, multimorbid patients are prone to receive fragmented, incomplete, inefficient, and ineffective care, which in turn may lead to unnecessary hospitalizations, increased use of emergency facilities, polypharmacy, adverse drug events, duplicative tests, and conflicting medical advices $[5,8,14,15]$.

Increasingly, comprehensive care programs are implemented in healthcare systems worldwide to address the integral healthcare demand of multimorbid patients $[5,16,17]$. Models are considered to be comprehensive if they address several healthcare needs of people with multiple chronic conditions, functional disabilities, and/or high healthcare utilization and if healthcare services are provided by multiple healthcare providers [17]. Comprehensive care programs are patient-centered and aim to structure and coordinate delivery of healthcare services $[5,16,17]$. Such programs are referred to as e.g. integrated care programs, disease management programs, guided care, transitional care or shared care [13,17]. By improving quality and continuity of care, these programs aim to improve patient health outcomes, whilst making efficient use of healthcare resources [13,18,19].

Reviews that provide an overview of implemented comprehensive care programs for patients with multiple chronic conditions indicate that evidence for their impact on patients and caregivers is inconsistent [17,20-25]. In most of these reviews criteria for the inclusion of studies were rather narrow. Some reviews predominantly 
Bruin, S.R. de, Versnel, N., Lemmens, L.C., Molema, C.C.M., Schellevis, F.G., Nijpels, G., Baan C.A. Comprehensive care programs for patients with multiple chronic conditions: a systematic literature review. Health Policy: 2012, 107(2-3), 108-145

included randomized controlled trials [17,21,23], whereas others just evaluated the impact of programs on patient outcomes [17,23-25] or included studies suggesting positive effects of comprehensive care programs [17]. Furthermore, most reviews provide limited information about the contents of the comprehensive care programs included. As a result, relevant information from non-randomized trials and information about the impact of programs on caregiver outcomes have hardly been summarized yet. Moreover, little is known about the program characteristics that may be related to positive outcomes of care and about the patient groups that may benefit most from comprehensive care. This information is, however, of importance since interest in what constitutes best care for patients with multimorbidity is growing. We therefore performed a thorough review of the literature using less narrow inclusion criteria than earlier review studies. We aimed to provide more insight into the characteristics of comprehensive care programs for patients with multiple chronic conditions and their impact on patients, informal caregivers, and professional caregivers.

\section{METHODS}

\subsection{Study design and search strategy}

We conducted a systematic literature search in the electronic databases Cinahl, Cochrane, Embase, Medline, PsycInfo, and SciSearch. The databases were searched for English language papers focusing on comprehensive care programs for people aged 18 years and older and published between January 1995 and January 2011. January 1995 was used as a starting point since from that year on comprehensive care has become an increasingly important focus of attention in the medical literature [26].

A comprehensive search strategy was developed by a librarian and two members of the project team (SdB and LL) to identify studies matching the following search terms (Medical Subject Headings): case management, comprehensive healthcare, critical pathways, disease management, continuity of patient care, patient care management, planning or team, patient-centered care, delivery of integrated healthcare, guided care, integrated care, managed care (programs), shared care, transmural care and variations of the keywords chronic disease, chronic illness, comorbidity, frailty, multimorbidity, multiple chronic conditions, and specific chronic conditions. These search terms were combined with variations of the following search terms: benefits, effects, effectiveness, efficacy, impact, outcomes, and specific (health) outcomes. In addition to the search in the electronic databases, relevant papers were identified through reference tracking and through a manual literature search on the internet. The internet was searched if the electronic database search yielded papers that reported on the design of an intervention study or a pilot intervention study. We then searched the internet to determine the status of these studies and to find out whether their results had already been published in scientific papers.

\subsection{Study selection}

Four reviewers (SdB, NV, LL, CM) worked in pairs and independently reviewed the papers yielded by the search for their relevance by screening their title and abstract. 
Bruin, S.R. de, Versnel, N., Lemmens, L.C., Molema, C.C.M., Schellevis, F.G., Nijpels, G., Baan C.A. Comprehensive care programs for patients with multiple chronic conditions: a systematic literature review. Health Policy: 2012, 107(2-3), 108-145

When considered relevant by both reviewers, the fulltext paper was retrieved. Any disagreement between the reviewers was resolved by consensus. In line with earlier studies [e.g. 27-31], the chronic care model (CCM) of Wagner et al. [18,32] was used to define comprehensive care. The model suggests that comprehensive care programs ideally comprise six interrelated components. Four components refer to the actual delivery of care by healthcare providers:

1. self-management support that helps patients and their families to obtain skills and confidence to manage their chronic condition (e.g. regular health education and coaching); 2. delivery system design that ensures the delivery of effective, efficient patient care through e.g. involvement of all members of the multidisciplinary team, planned patient interactions, regular follow-up, and case management; 3. decision support by evidence-based guidelines providing clinical standards for high-quality chronic care, and 4. development of clinical information systems that supply care teams with feedback, remind them to comply with practice guidelines, provide registries for planning individual and population-based care, and enable proactive interactions between caregivers and patients. The two remaining components refer to the context in which chronic care is provided: 5 . the healthcare system that provides the organizational context in which chronic care is provided and encompasses the aforementioned components. A healthcare system that endorses improvement of the quality of care must be well-organized, motivated, and prepared to change; and 6 . links towards community resources and policies. The healthcare system is embedded in a community that includes organizations and programs that may support or expand a healthcare system's care for chronically ill patients (e.g. senior centers that address social issues of patients or fitness centers that offer physical activity programs) $[32,33]$. In our study, only comprehensive care programs that included interventions related to two or more components of the CCM were included. We decided on a minimum of two components since, according to the CCM, components must be interrelated.

For the present study, papers were eligible if they met the following inclusion criteria: 1. the program described in the paper met our operational definition of comprehensive care; 2 . the target population of the program consisted of people with multiple chronic conditions; and 3. the study described in the paper was an intervention study evaluating the impact of a comprehensive care program. Duplicate studies were identified and excluded.

\subsection{Data extraction, quality assessment, and data analysis}

Four authors (SdB, NV, LL, CM) worked in pairs to extract relevant data from the studies included. Data extracted from the papers were: 1 . study design; 2 . length of follow-up of study; 3. target population of the program; 4. setting in which the program had been implemented; 5 . content of the program described in terms of the CCM components; 6 . characteristics of the usual care condition; and 7. study outcomes. Our analyses were descriptive and qualitative in nature.

Of the studies that compared healthcare costs of comprehensive care with those of usual care, we reported the incremental healthcare costs of comprehensive care. Incremental costs can be defined as the difference in healthcare costs for patients receiving comprehensive care and those for patients receiving care as usual. Negative incremental costs imply that healthcare costs for patients receiving comprehensive care are lower than those for patients receiving usual care. Positive incremental costs 
Bruin, S.R. de, Versnel, N., Lemmens, L.C., Molema, C.C.M., Schellevis, F.G., Nijpels, G., Baan C.A. Comprehensive care programs for patients with multiple chronic conditions: a systematic literature review. Health Policy: 2012, 107(2-3), 108-145

imply that healthcare costs for patients receiving comprehensive care are higher than those for patients receiving usual care. For the present paper, we only report incremental direct healthcare costs, such as costs of primary care visits, emergency room (ER) visits, and hospitalization. Cost estimates were adjusted for cross-country purchasing power differences (PPP), using 2008 US\$ PPP, and for inflation, using Gross Domestic Product prices in order to make meaningful comparisons across studies [34]. Four studies did not report the year of data collection. For these studies the year of publication was used as reference year.

The methodological quality of the selected studies was scored independently by three reviewers (SdB, NV, CM) on the basis of six items adapted from two quality criteria lists [35,36] (Table 2). Our list included criteria that in our opinion were most relevant for studies on comprehensive care. The reviewers rated each criterion as ' + ' (i.e. criterion fulfilled), '-' (i.e. criterion not fulfilled), '?' (i.e. lack of information) or 'N.A.' (i.e. not applicable). Since we did not use a complete standardized set of assessment criteria, we decided not to assign an overall quality rating per study. Hence, we only provide a total quality sum-score (ranging from 0 to 6 ) per study that was determined by counting the number of criteria scored positively. To draw conclusions regarding the effectiveness of comprehensive care programs, in line with earlier studies a best-evidence analysis was applied [37-39]. We distinguished four levels to rate the strength of evidence for each of the outcomes:

1. Strong evidence: consistent evidence for a beneficial effect of comprehensive care across multiple studies with high quality sum-scores;

2. Moderate evidence: consistent evidence for a beneficial effect of comprehensive care across multiple studies, including at least one study with a high quality sumscore and studies with lower quality sum-scores;

3. Insufficient evidence: inconsistent evidence for a beneficial effect of comprehensive care across multiple studies;

4. No evidence: only few studies available and/or consistent evidence for no effect of comprehensive care across multiple studies.

Similar to previous reviews that applied a best-evidence synthesis $[37,38]$ results were considered consistent when at least $75 \%$ of the studies showed results in the same direction. Findings of studies with relatively higher quality sum-scores were valued more than findings of studies with relatively lower quality sum-scores.

\section{RESULTS}

\subsection{Study retrieval}

Our literature search yielded 3544 potentially relevant publications. On the basis of their title and abstract, 184 papers were selected by the reviewers to be retrieved fulltext for in-depth screening. This screening process resulted in 32 publications for inclusion in our study. The addition of 10 papers from our manual search resulted in a total of 42 publications that were classified as eligible for our review. Reasons for exclusion are shown in Fig. 1. 
Bruin, S.R. de, Versnel, N., Lemmens, L.C., Molema, C.C.M., Schellevis, F.G., Nijpels, G., Baan C.A. Comprehensive care programs for patients with multiple chronic conditions: a systematic literature review. Health Policy: 2012, 107(2-3), 108-145

\section{[FIGURE 1]}

\subsection{Study characteristics}

\subsubsection{Study designs and length of follow-up}

The 42 included publications described 33 different studies i.e. fourteen randomized controlled trials, eight pretest-post-test studies, five controlled clinical trials, three cluster randomized controlled trials, two post-test only studies, and one case control study (Table 1). Across all studies, sample size varied from 25 to 65,132 subjects. Of the studies with a longitudinal design, twenty studies had a follow-up of $\leq 12$ months and seven studies had a followup of $>12$ months. In three studies the length of follow-up was variable (e.g. depending on time to discharge).

\subsubsection{Methodological quality of studies}

None of the studies fulfilled all quality criteria (i.e. sum-score of 6) based on what could be retrieved from the information provided in the papers (Table 2). The observed minimum sum-score was $0(n=6)$ and the maximum sum-score was $5(n=$ 1). The quality criteria "similar at baseline" and "drop-out rate" were most frequently scored positively. Only three papers reported enough information to assess the quality criterion regarding compliance [40-42]. The quality criteria "randomization", "similarity at baseline", "application of intention-to-treat-analysis", and "adjustment for confounders" were not applicable for studies with a non-experimental design ( $\mathrm{n}=$ $11)$.

\section{[TABLE 1 AND TABLE 2]}

\subsubsection{Usual care conditions}

In most studies $(n=23)$ the effects of comprehensive care programs were compared with those of care as usual (i.e. no comprehensive care). In twelve of these studies, the usual care conditions were not or only poorly described (Table 1). Usual care was mostly described as normal access to services available to frail older people, routine home, primary and hospital care, and/or encouragement to remain in care of their current physician.

\subsection{Program characteristics}

\subsubsection{Target populations}

The 33 different studies evaluated 28 different comprehensive care programs. The comprehensive care programs were implemented in the USA $(n=17)$, Canada $(n=$ 4), Australia $(n=3)$, Italy $(n=1)$, Norway, $(n=1)$, United Kingdom $(n=1)$, and one program was implemented in both the Netherlands and the USA. Fifteen comprehensive care programs focused on frail people aged 65 years and older with multiple, not specified chronic conditions, functional disabilities, complex healthcare needs, and/or high use of healthcare services [11,43-64]. Seven programs focused on multimorbid older people who were (acutely) hospitalized and who sometimes had a history of readmissions or were at risk for readmissions [65-74]. Five programs focused on older people with (a combination of) specific chronic conditions such as 
Bruin, S.R. de, Versnel, N., Lemmens, L.C., Molema, C.C.M., Schellevis, F.G., Nijpels, G., Baan C.A. Comprehensive care programs for patients with multiple chronic conditions: a systematic literature review. Health Policy: 2012, 107(2-3), 108-145

diabetes mellitus, heart failure, COPD, dementia and/or arthritis [40,42,75-79], and one program focused on people aged 50 years or older who were at risk of functional decline or physical deterioration [41] (Table 1).

\subsubsection{Settings}

The settings in which the comprehensive care programs were implemented varied from home care organizations and community centers to primary care practices, hospitals, specialized clinics (e.g. geriatric clinics and Veterans Affairs medical centers), and managed care organizations (Table 1). Consequently, the type of care that was provided also differed widely between the programs. Various comprehensive care programs incorporated a mix of care types, such as the Integrated Services for Frail Elders (SIPA) and the Nurse Physician Collaborative Partnership in Canada, the Integrated Community Care for Older People (ICCOP) in Australia, and the Health Enhancement Project (HEP) in the USA. These programs mostly included newly established partnerships between community centers, home care organizations, primary care practices, and/or hospitals [43,56,57,60]. Other programs enabled the provision of regular care services in settings in which they were not normally provided, such as the Older Hospitalized Patients' Discharge Planning and In-home Follow-up Protocol in Australia and the Geriatric Home Hospitalization Service in Italy both providing hospital care services at home $[67,71]$.

\subsubsection{Contents}

Table 1 presents the contents of the comprehensive care programs included in our review. The table illustrates the diversity in the comprehensive care programs with regard to the number of included interventions and the number of related CCM components. We observed comprehensive care programs that included interventions related to two CCM components $(n=5)$, three CCM components $(n=12)$, four CCM components $(n=3)$, five CCM components $(n=6)$, and six CCM components $(n=$ 2).

Except for one program [75], all comprehensive care programs included interventions related to the CCM component delivery system design. Examples are employing a case manager, working in multidisciplinary teams, designing individualized care plans, and making home visits to patients. The majority of comprehensive care programs $(n=25)$ additionally included interventions related to the CCM component self-management support, such as involving patients in the design of their care plan, educating patients to improve self-management, and stimulating patients to participate in self-management group sessions. Twenty comprehensive care programs included interventions related to the CCM component decision support. Interventions to support healthcare providers' decision-making included implementing evidence-based guidelines, training teams to implement new protocols, and supervising newly appointed case managers. Interventions related to the CCM components clinical information systems (e.g. feedback sheets, electronic patient records, and telehomecare units) and community resources (e.g. establishing access to community resources and partnerships with local community service centers) were less frequently observed ( $\mathrm{n}=12$ for both components). A small 
Bruin, S.R. de, Versnel, N., Lemmens, L.C., Molema, C.C.M., Schellevis, F.G., Nijpels, G., Baan C.A. Comprehensive care programs for patients with multiple chronic conditions: a systematic literature review. Health Policy: 2012, 107(2-3), 108-145

minority of the comprehensive care programs $(n=4)$ included interventions related to the CCM component health system. Examples of such interventions are installing committees to support new partnerships, employing management teams to support process and quality improvement, and enabling infrastructure for innovations in chronic care.

\subsection{Impact of comprehensive care programs}

Table 1 presents all outcomes reported in the studies included. Only outcomes that were reported in at least five studies are described in the text. More detailed information about the actual differences between comprehensive care groups and usual care groups or about actual changes over time for clinical outcomes are provided in Tables 3a and 3b, respectively. Quality of reporting on baseline and followup scores on the clinical patient outcomes widely varied across studies.deteriorated in the usual care group [79]. Two studies did not compare comprehensive care with usual care [55,60]. Mitton et al. [60] observed no significant change in cognitive functioning over time, whereas Duke et al. [55] suggested a deterioration of cognitive functioning over time. Considering these findings, there is no evidence for a beneficial effect of comprehensive care on cognitive functioning.

\subsubsection{Depressive symptoms.}

Seven studies measured the effect of comprehensive care on depressive symptoms of which three had relatively higher quality sumscores $[50,56,58]$. Five studies reported no differences between comprehensive care and usual care groups [50,56,61,68,76]. Two studies, however, reported a significantly larger reduction of depressive symptoms in the comprehensive care group than in the usual care group $[58,66]$. Considering these findings, there is no evidence for a beneficial effect of comprehensive care on depressive symptoms.

\subsubsection{Functional status.}

Nine studies evaluated the effects of comprehensive care on activities of daily living (ADL), of which three had relatively higher quality sum-scores [51,56,74]. Six studies reported no differences between comprehensive care and usual care groups $[51,61,66,68,73,74]$. Two studies reported a significantly larger improvement of ADL in the comprehensive care group compared to the usual care group [56,79]. Mitton et al. [60] presented the results of comprehensive care only, showing no effects on ADL.

\section{[TABLE 3]}

The effect of comprehensive care on instrumental activities of daily living (IADL) was evaluated in six studies, of which one had a relatively higher quality sum-score [51]. Five studies observed no effect of comprehensive care on IADL

$[51,61,66,68,73]$ while one study observed significant improvement of IADL in the comprehensive care group and significant deterioration in the usual care group [79]. Frequency of falls was evaluated in two studies [50,61]. Both studies found no difference between the effect of comprehensive care and usual care. One study 
Bruin, S.R. de, Versnel, N., Lemmens, L.C., Molema, C.C.M., Schellevis, F.G., Nijpels, G., Baan C.A. Comprehensive care programs for patients with multiple chronic conditions: a systematic literature review. Health Policy: 2012, 107(2-3), 108-145

evaluated the effect of comprehensive care on physical performance and reported no effect of comprehensive care [56].

Considering these findings, there is no evidence for a beneficial effect of comprehensive care on functional status.

\subsubsection{Health behavior.}

Health behavior, including physical activity, dietary habits, and immunization compliance, was evaluated in five studies. Overall, quality sum-scores of these studies were low. One study observed that health behavior (i.e. exercise) improved significantly more in the comprehensive care group than in the usual care group [56], whereas one study found no effect of comprehensive care on health behavior (i.e. exercise and cognitive symptom management) [77]. The studies that did not compare comprehensive care with usual care found a (significant) improvement of behavior towards, diet, exercise, immunization or medication but not towards cognitive symptom management $[40,64,78]$. Considering these findings, there is moderate evidence for a beneficial effect of comprehensive care on health behavior.

\subsubsection{Health-related quality of life.}

Effectiveness of comprehensive care regarding health-related quality of life was reported in seventeen studies including six with relatively higher quality sum-scores $[50,51,56,58,67,74]$. Studies differed widely in the definition and measurement of health-related quality of life. Thirteen studies compared health-related quality of life between patients receiving comprehensive care and patients receiving usual care. Nine of these studies reported no differences between comprehensive care and usual care groups [40,50,56,61,65,73,74,76,77]. Two studies reported that comprehensive care favored usual care in terms of mental functioning but not in terms of physical functioning [51,58]. Courtney et al. [67] observed that comprehensive care favored usual care in terms of mental as well as in terms of physical functioning. Also Zhang et al. [75] observed for the majority of aspects of quality of life a significant effect of comprehensive care (i.e. significantly slower deterioration than in the usual care group). Four studies did not compare comprehensive care with usual care $[55,60,64,78]$, with two studies observing an improvement in quality of life over time due to comprehensive care $[55,64]$. Considering the inconsistent findings across studies, there is insufficient evidence for a beneficial effect of comprehensive care on quality of life in terms of mental functioning. Almost none of the studies, including those with relatively higher quality sum-scores, reported positive effects of comprehensive care on health-related quality of life in terms of physical functioning. Considering these findings, there is no evidence for a beneficial effect of comprehensive care on quality of life in terms of physical functioning.

\subsubsection{Medication use.}

Six studies evaluated the effect of comprehensive care on medication use. Most of these studies had relatively low quality sum-scores. Two studies found no differences between comprehensive care and usual care groups $[50,66]$. Three studies, however, observed that comprehensive care favored usual care in terms of medication 
Bruin, S.R. de, Versnel, N., Lemmens, L.C., Molema, C.C.M., Schellevis, F.G., Nijpels, G., Baan C.A. Comprehensive care programs for patients with multiple chronic conditions: a systematic literature review. Health Policy: 2012, 107(2-3), 108-145

compliance, medication appropriateness, antipsychotic and unnecessary drug use, detection of adverse drug reactions, and conditions with omitted drugs [40,70,71]. One study did not compare comprehensive care with usual care but also reported an improvement in medication management due to comprehensive care [62]. Considering the inconsistent findings across studies, there is insufficient evidence for a beneficial effect of comprehensive care on medication use.

\subsubsection{Mortality.}

Mortality was evaluated in six studies (Table 3b) [51,54,69,71,73,74], of which most had relatively low quality sum-scores. Two of these studies found a significantly lower mortality rate and/or a significantly longer time to death in the comprehensive care group than in the usual care group [54,74]. In one of these studies, however, this effect was only observed for a subgroup of patients with complex diseases including diabetes mellitus [54]. Considering the fact that almost none of the studies, including those with relatively higher quality sumscores, reported positive effects of comprehensive care on mortality, there is no evidence for a beneficial effect of comprehensive care on mortality.

\subsubsection{Perceived quality of care and satisfaction.}

Fourteen studies measured perceived quality of care and patient satisfaction. Five studies compared effects of comprehensive care and usual care [44,48,50,51,74]. Four had relatively high quality sum-scores. Two studies found significantly higher perceived quality of care or satisfaction with care in the comprehensive care group than in the usual care group [44,74]. Two studies observed no differences between comprehensive care and usual care groups [50,51]. One study found that comprehensive care favored usual care for some aspects of care (e.g. quality of patient-physician communication) whereas for other aspects no differences were found (e.g. physician's knowledge of patient, quality of integration of care, trust in physician) [48].

Nine studies only reported outcomes for patients receiving comprehensive care and found that the majority of patients were satisfied with the program. Patients found the comprehensive care program helpful and user-friendly, and appreciated the holistic approach. They further believed that the program helped them to manage their disease, had improved their health, and made it easier to get access to healthcare services [11,40-42,60,62,64,76,77]. Considering the fact that two studies with relatively high quality sum-scores reported positive effects of comprehensive care on quality of care and satisfaction and that these findings were supported by qualitative findings, there is moderate evidence for a beneficial effect of comprehensive care on quality of care and patient satisfaction.

\subsubsection{Patient related outcomes-economic outcomes}

\subsubsection{Healthcare utilization and healthcare costs.}

Twentyfive studies evaluated the effect of comprehensive care on healthcare utilization and/or healthcare costs (Table 1). We distinguish the effect on inpatient 
Bruin, S.R. de, Versnel, N., Lemmens, L.C., Molema, C.C.M., Schellevis, F.G., Nijpels, G., Baan C.A. Comprehensive care programs for patients with multiple chronic conditions: a systematic literature review. Health Policy: 2012, 107(2-3), 108-145

healthcare utilization and outpatient healthcare utilization. Twenty-one studies measured the utilization of inpatient healthcare services.

Sixteen studies compared inpatient healthcare utilization between patients receiving comprehensive care and patients receiving usual care, including seven with relatively high quality sum-scores $[43,46,50,52,56,67,74]$. Studies differed widely in the definition and measurement of utilization of inpatient healthcare services (e.g. number of ER visits, hospital readmission rate, length of hospital stay, number of hospitalizations, and percentage of patients using nursing home care).

Comprehensive care favored usual care in six studies [51,56,67,72,74,75]. In two of these studies the ER visit rate was significantly lower in the comprehensive care group than in the usual care group [51,75]. In three studies the number of hospital (re)admissions was significantly lower and/or the time to readmission significantly longer in the comprehensive care group than in the usual care group $[67,74,75]$. In one study length of hospital stay significantly decreased in the comprehensive care group whereas it significantly increased in the usual care group [56]. Two studies observed significant differences between comprehensive are and usual care groups that were not in favor of comprehensive care [43,54]. One of these studies found significantly more ER visits in the comprehensive care group than in the usual care group [54]. The other study found significantly higher utilization of nursing home care in the comprehensive care group than in the usual care group [43]. No significant differences were observed for other parameters measured in these studies. Eight studies that compared utilization of inpatient healthcare services between patients receiving comprehensive care and patients receiving usual care observed no significant differences between the groups for any of the parameters that were measured $[40,46,49,50,61,65,66,76]$. Although differences in the utilization of inpatient healthcare services were mostly not significant, five studies that also measured healthcare costs, reported negative incremental direct healthcare costs (i.e. lower direct healthcare costs for patients receiving comprehensive care than for patients receiving usual care). Across these studies, of which four had relatively high quality sum-scores $[43,46,50,74]$, incremental healthcare costs ranged from $-\$ 5708$ to $-\$ 204$ per patient per year $[43,46,49,50,74]$. This was primarily due to lower inpatient healthcare costs in the comprehensive care group than in the usual care group.

Five of the twenty-one studies that measured utilization of inpatient healthcare services did not compare comprehensive care with usual care [42,55,57,60,78]. One of these studies reported no significant change over time in ER visits, hospitalizations, and length of hospital stay [78]. In the other studies change over time was not tested for significance. These studies, however, observed reductions in the use of hospital care and ER visits. Reductions in hospitalizations varied from $38 \%$ to $69 \%[42,55,60]$. Reductions in the length of hospital stay varied from $37 \%$ to $64 \%[55,57,60]$. Reductions in the number of ER visits ranged from 32\% to 54\% $[55,57,60]$. These findings are in line with the findings of the studies that reported direct inpatient healthcare costs for the comprehensive care group only $[11,55,60,63,72,75]$. Two of these studies reported cost savings ranging from $\$ 3029$ to $\$ 6198$ per patient per year. These savings were primarily due to less hospitalizations and ER visits, and reduced length of hospital stay during (re)admission [60,72]. Four other studies that only reported direct healthcare costs for the comprehensive care group reported cost reductions due to comprehensive care 
Bruin, S.R. de, Versnel, N., Lemmens, L.C., Molema, C.C.M., Schellevis, F.G., Nijpels, G., Baan C.A. Comprehensive care programs for patients with multiple chronic conditions: a systematic literature review. Health Policy: 2012, 107(2-3), 108-145

ranging from $\$ 147,000$ to $\$ 1.8$ million per year for patients included in the study which again were primarily due to significant reduced numbers of ER visits and hospitalizations or a reduced length of hospital stay [11,55,63,75].

Six studies measured utilization of outpatient healthcare services $[40,43,46,56,65,76]$, of which three had relatively high quality sum-scores $[43,46,56]$. All studies compared comprehensive care with usual care. Béland et al. [43] observed significantly more GP visits, home care visits, and visits to day hospitals in the comprehensive care group than in the usual care group. This resulted in significantly higher outpatient healthcare costs in the comprehensive care group than in the usual care group. These findings are supported by the study that reported positive incremental healthcare costs of \$1321 per patient per year (i.e. higher healthcare costs in the comprehensive care group) [52]. In this study, costs for chronic (including comprehensive care) and preventive care were significantly higher in the comprehensive care group. Leveille et al. [56] observed significantly higher senior centre participation in the comprehensive care group than in the usual care group, whereas Kobb et al. [40] observed significantly less outpatient and pharmacy visits in the comprehensive care group than in the usual care group. Four studies observed no differences in utilization of (other) outpatient healthcare services between comprehensive care and usual care groups [46,56,65,76].

Two studies did not specify costs for inpatient and outpatient healthcare services $[58,64]$. One study compared healthcare costs of the comprehensive care group with these of the usual care group, and found no effect of comprehensive care [58]. The other study reported only healthcare costs for the comprehensive care group and observed that the actual healthcare costs were significantly lower than the projected healthcare costs [64].

Although quality sum-scores and findings differed across studies, there were six studies with relatively high quality scores and five studies with relatively lower quality scores that reported decreased inpatient healthcare utilization and/or decreased healthcare costs due to comprehensive care. Based on these findings, there is moderate evidence for a beneficial effect of comprehensive care on inpatient healthcare utilization and healthcare costs. Two studies with relatively high quality sum-scores observed higher outpatient healthcare utilization due to comprehensive care groups. These findings were, however, not supported by the studies with relatively lower quality sum-scores. Moreover, the four studies that observed differences between comprehensive care and usual care groups widely differed in the measurement of utilization of outpatient healthcare services. Considering these findings, there is insufficient evidence for an effect of comprehensive care on outpatient healthcare utilization.

\subsubsection{Informal caregiver related outcomes}

Six studies reported the effect of comprehensive care on informal caregivers. Outcomes varied from depressive symptoms and caregiver strain to caregiver's productivity loss, satisfaction, and perceived quality of care. Two studies compared effects of comprehensive care with usual care [47,71]. Quality sum-scores of these studies were rather low. One of these studies reported significantly higher perceived quality of care in caregivers of patients enrolled in a comprehensive care program than in those of patients that received usual care, but found no effect of comprehensive care on caregiver depression, caregiver strain, and productivity loss 
Bruin, S.R. de, Versnel, N., Lemmens, L.C., Molema, C.C.M., Schellevis, F.G., Nijpels, G., Baan C.A. Comprehensive care programs for patients with multiple chronic conditions: a systematic literature review. Health Policy: 2012, 107(2-3), 108-145

[47]. Tibaldi et al. [71], however, observed a significantly larger reduction of caregiver strain in caregivers of patients that received comprehensive care than in caregivers of patients that received usual care. Considering these findings, there is no evidence for a beneficial effect of comprehensive care on caregiver burden. Four studies only reported outcomes for caregivers of patients that received comprehensive care and observed that caregivers were satisfied with the program [41,60], experienced an improvedability to cope with the disease of their family member, and experienced less anxiety and caregiver burden [42,60,62]. Although quality sum-scores of these studies were rather low, these studies' findings were rather consistent. Considering these findings, there is moderate evidence for a beneficial effect of comprehensive care on satisfaction of informal caregivers.

\subsubsection{Professional caregiver related outcomes}

Nine studies reported the effect of comprehensive care on professional caregivers. Outcomes varied from satisfaction and knowledge to experiences with processes of care. Two studies compared outcomes of caregivers providing comprehensive care with those of caregivers providing usual care $[45,59]$. Quality sum-scores of these studies were relatively low. Both studies observed that caregivers providing comprehensive care were significantly more satisfied with communication with patients and family members and some aspects of their knowledge than caregivers providing usual care. They did not report any differences in time spent on patient care and care coordination.

Seven studies only reported outcomes for caregivers providing comprehensive care and observed that the majority of caregivers expressed high levels of satisfaction with e.g. communication with other healthcare providers and newly established partnerships. They further indicated to be better able to meet the needs of frail older patients and that the program decreased time spent on patient care $[11,40,41,50,60,76]$. One study suggested that comprehensive care enabled early detection and treatment of problems [42]. Although quality sum-scores of the two studies that compared outcomes of caregivers providing comprehensive care with those of caregivers providing usual care were rather low, their findings were in line with the qualitative findings of the other studies. Considering these findings, there is moderate evidence for a beneficial effect of comprehensive care on satisfaction of professional caregivers.

\section{DISCUSSION}

This systematic literature review summarizes available information about the characteristics of comprehensive care programs for people with multiple chronic conditions and about their impact on patients and caregivers. There is a vast amount of literature on comprehensive care. However, most literature focuses on comprehensive care programs for people with a single disease [e.g. 19,29-31,82,8385]. Our work focuses on comprehensive care programs for people with multiple diseases, and therefore adds to the current literature. Research on multimorbidity is still in its infancy $[6,14,75]$. With this review we therefore aimed to contribute to a scientific basis for the improvement of care for patients with multimorbidity. 
Bruin, S.R. de, Versnel, N., Lemmens, L.C., Molema, C.C.M., Schellevis, F.G., Nijpels, G., Baan C.A. Comprehensive care programs for patients with multiple chronic conditions: a systematic literature review. Health Policy: 2012, 107(2-3), 108-145

We conducted a thorough systematic review of thirty-three studies that examined twenty-eight different comprehensive care programs for multimorbid patients. Although our study includes more recent studies than earlier review studies on the same subject [17,20-25], evidence regarding the effectiveness of comprehensive care remains inconsistent. Overall, the effects of comprehensive care were comparable to or more positive than those of usual care. Moderate evidence was found for a beneficial effect of comprehensive care on inpatient healthcare utilization and healthcare costs. Moderate evidence was also found for a beneficial effect of comprehensive care on health behavior of patients, perceived quality of care, and satisfaction of patients and caregivers. Insufficient evidence was found for a beneficial effect of comprehensive care on health-related quality of life in terms of mental functioning, medication use, and outpatient healthcare utilization and healthcare costs. No evidence was found for a beneficial effect of comprehensive care on cognitive functioning, depressive symptoms, functional status, mortality, quality of life in terms of physical functioning, and caregiver burden.

The majority of comprehensive care programs incorporated interventions related to three or more CCM components. As observed in recent studies on comprehensive care programs for people with a single disease [27-30,86], also almost all comprehensive care programs for people with multiple chronic diseases included interventions related to the CCM components delivery system design and selfmanagement support. In contrast to these studies, however, several programs reviewed in our study included interventions promoting access to community resources. Such interventions were particularly part of the programs for frail older people and were mostly designed as partnerships between primary care practices or hospitals and local community service centres to establish easy access to community resources (e.g. transportation, meals, and adult day care) for patients and assessment of patient needs regarding community services [e.g. 43,45,53,56,60]. This may well reflect an increasing attention for social issues of multimorbid patients. This is an important finding since the integration of medical and social services is advocated to optimize care for patients with multiple chronic conditions $[11,87]$.

The diversity in the effects of comprehensive care programs may be related to the substantial variation in the programs in terms of target patient groups, design of the intervention/program, and settings in which they were implemented. It is hard to determine to which program components positive effects could be attributed and under which circumstances comprehensive care programs may be most effective. The diversity in the effects of comprehensive care programs may also be related to whether the programs were correctly implemented, whether the program components were integrated, and whether they were fully adopted by the patients and the caregivers involved. The level of implementation of the comprehensive care programs was discussed in few studies only. Explanations proposed for a lack of positive effects of comprehensive care were inadequate integration of newly developed interventions in daily practice, insufficient understanding of the care innovations among caregivers involved, inadequate skills for implementing the innovations, insufficient time to adapt to newly implemented care models, and noncompliance of patients [43,51,65,67].

Finally, the wide variety in the study results may also be related to differences in usual care conditions. Our study yielded comprehensive care programs from seven countries. As was also suggested in studies on comprehensive care programs for 
Bruin, S.R. de, Versnel, N., Lemmens, L.C., Molema, C.C.M., Schellevis, F.G., Nijpels, G., Baan C.A. Comprehensive care programs for patients with multiple chronic conditions: a systematic literature review. Health Policy: 2012, 107(2-3), 108-145

patients with a single-disease [83,88], differences in healthcare systems between countries and between settings within countries, and differences in usual care settings are to be expected. Information about the usual care conditions tended to be poor, which made it hard to distinguish the usual care conditions from the comprehensive care conditions. Consequently, it is often not possible to determine whether differences in study results could be related to differences in comprehensive care programs or to differences between comprehensive care and usual care.

Although our study provided insight into the characteristics of a large number of available programs for multimorbid patients and into their potential effects, we should acknowledge its limitations. A limitation of our search strategy is that we included scientific papers written in the English language only. Therefore, we may have missed relevant comprehensive care programs.

Another limitation was that we could not use a complete standardized tool to assess the methodological quality of the included studies. The usefulness and relevance of existing assessment instruments are limited as several of the quality assessment criteria are not applicable to studies on comprehensive care [89]. Also the Health Technology Assessment-Disease Management (HTA-DM) instrument [89] which was specifically developed to assess the quality of complex interventions such as comprehensive care has limitations and needs further validation $[28,90]$. We therefore decided to select six criteria from existing quality criteria lists $[35,36]$ that in our opinion were most relevant for the assessment of studies on comprehensive care programs. With this approach, we aimed to provide some insight into the quality of the included studies and into the strength of evidence. Quality assessment was sometimes, however, hampered by poor or lacking information in the papers. Furthermore, four quality criteria did not apply to studies with non-experimental study designs. Consequently, these studies have been assigned lower quality sumscores, suggesting lower study quality, which may not be justifiable. It should further be noted that our study did not only aim to determine the effectiveness of comprehensive care programs but also to determine the characteristics of comprehensive care programs. Like papers describing studies with higher quality sum-scores, the papers describing studies with relatively lower quality sum-scores could therefore also provide relevant information regarding the characteristics of comprehensive care programs.

The consequences of including studies irrespective of their methodological quality were that we observed variation in study designs and length of follow-up. Moreover, we observed a wide variety in outcome measurements and how they were made operational, and a high rate of missing data (e.g. standard deviations for mean values). These issues are generally acknowledged by researchers investigating comprehensive care [21-23,91-93]. Against this backdrop we considered estimating an average effect of comprehensive care by means of meta-analysis of little value.

Hence, we limited ourselves to qualitative comparisons of the results of the included studies. It was further hard to determine which number of CCM components and which combinations are most promising.

These findings are not unique to comprehensive care programs for patients with multiple chronic conditions. Likewise, recent studies focusing on comprehensive care programs for people with a single-disease suggest that it is hard to determine to which number and to which components positive effects of comprehensive care can be attributed $[27,30,31,84]$. A study focusing on programs with a single-disease 
Bruin, S.R. de, Versnel, N., Lemmens, L.C., Molema, C.C.M., Schellevis, F.G., Nijpels, G., Baan C.A. Comprehensive care programs for patients with multiple chronic conditions: a systematic literature review. Health Policy: 2012, 107(2-3), 108-145

approach suggests that programs that contain interventions related to at least one CCM component improve clinical outcomes and processes of care [29]. For COPD patients significant effects on hospitalizations and ER visits have been found for programs that contained interventions related to at least two CCM components $[28,31]$. For other outcomes or in other studies focusing on comprehensive care programs for COPD patients it was observed that programs should include interventions that related to at least three or even four CCM components to be effective [28,93].

Also with regard to the type of CCM components mixed results have been reported. Some studies suggest that the CCM components self-management support, delivery system design, and decision support are associated with better clinical outcomes and/or processes of care [29,30]. Another study, however, failed to find an association between the elements self-management support or delivery system design and clinical outcomes [94]. The CCM has, however, been promoted as a unified package; the different CCM components are supposed to have a synergistic effect in which the whole is greater than the sum of the parts [29,84].

The finding that comprehensive care programs may be effective in terms of reducing healthcare utilization and as a result in reducing healthcare costs is promising. The increasing prevalence of chronic diseases has major economic consequences for healthcare systems, and it is therefore important to have insight into strategies that may reduce healthcare costs. However, comprehensive care programs are not only implemented to make efficient use of healthcare resources, but also to improve patient health outcomes. In line with other recent studies, we found hardly any studies that suggested a positive effect of comprehensive care on clinical patient outcomes (i.e. cognition, depressive symptoms, functional status, mortality). An important explanation for this finding, which was also suggested by others [21], may be that multimorbid patients are too a heterogeneous group with large variations in the progression of their diseases and impairments. Conditions may be too severe to be affected by the interventions offered and the time too short to establish an effect $[51,95,96]$. Moreover, in most studies standardized assessment tools were used to evaluate effects of comprehensive care on patient health outcomes. It has been suggested that such instruments are not sufficiently sensitive to capture clinically important changes over time that can be attributed to comprehensive care programs $[97,98]$.

To support decision-making in the field of chronic care for patients with multiple chronic conditions, it is necessary to enhance comparability between studies. It is therefore recommended to better describe the comprehensive care programs, their level of implementation, and the usual care conditions to which their effectiveness is compared. Only then more consistent evidence for their effectiveness may be obtained. Since there are indications that comprehensive care for patients with multiple chronic conditions may be cost-saving, it is further recommended to perform more rigorous economic evaluations that include similar cost dimensions and take both costs and effects of comprehensive care into account. Our study revealed substantial variation in the costs that were taken into account in the included studies (e.g. inpatient costs, outpatient costs, costs of comprehensive care program), which hampers comparability of their results. Insight into the economic effects of comprehensive care, in particular the incremental costs of the programs, are of 
Bruin, S.R. de, Versnel, N., Lemmens, L.C., Molema, C.C.M., Schellevis, F.G., Nijpels, G., Baan C.A. Comprehensive care programs for patients with multiple chronic conditions: a systematic literature review. Health Policy: 2012, 107(2-3), 108-145

primary interest, since they provide information about the potential added value of comprehensive care as compared to usual care.

In addition, more insight is needed into the impact of comprehensive care on caregiver burden. Literature suggests that caregiver burden is a predictor of institutionalization of frail older people, particularly those with dementia [99]. Older people are increasingly stimulated to live independently for as long as possible. Future studies should therefore examine the effect of comprehensive care on predictors of institutionalization, such as caregiver burden, to be able to establish whether comprehensive care programs may delay or prevent institutionalization. It is further recommended to gain more insight into patient and caregiver satisfaction, and perceived quality of care. Most studies included in this review measured these outcomes only after the implementation of the comprehensive care program and did not compare these outcomes with (family caregivers of) patients receiving usual care and professional caregivers providing usual care. It is therefore recommended to measure satisfaction and perceived quality of care both before and after the implementation of the comprehensive care program and thus be able to determine the effect of comprehensive care. Such information is valuable since it may provide insight into processes underlying positive or negative outcomes of care.

Finally, in line with the client-centered approach in healthcare it is recommended to incorporate individual goals and individual preferences and needs in the evaluation of comprehensive care programs for multimorbid patients. Such methods (e.g. Goal Attainment Scaling) may be more meaningful and more sensitive to detect clinically important change related to comprehensive care than standard assessment tools that are mostly used [97,98].

\section{CONCLUSION}

There is a broad array of comprehensive care programs available to patients with multiple chronic conditions that often integrate both medical and social services. Despite indications that comprehensive care programs for multimorbid patients decrease inpatient healthcare utilization and healthcare costs, improve health behavior of patients and perceived quality of care, and realize satisfaction of patients and caregivers because of the heterogeneity of the programs it is as yet too early to draw firm conclusions regarding their effectiveness. It remains hard to determine which patient groups benefit most from comprehensive care and which program characteristics contribute most to positive effects of comprehensive care. More consistently performed evaluation studies are necessary to determine what constitutes best care for the increasing number of people with multiple chronic conditions.

\section{REFERENCES}

[1] World Health Organization. The global burden of disease, 2004 update. Retrieved 2 February 2011, from: http://www.who.int/ healthinfo/global burden disease/GBD report 2004update full.pdf.

[2] World Health Organization. The European health report 2009: health and health systems. Copenhagen: World Health Organization; 2009.

[3] World Health Organization. Preventing chronic diseases: a vital investment. Retrieved 2 February 2011, from: http:// whqlibdoc.who.int/publications/2005/9241563001 eng.pdf. 
Bruin, S.R. de, Versnel, N., Lemmens, L.C., Molema, C.C.M., Schellevis, F.G., Nijpels, G., Baan C.A. Comprehensive care programs for patients with multiple chronic conditions: a systematic literature review. Health Policy: 2012, 107(2-3), 108-145

[4] Marengoni A, Winblad B, Karp A, Fratiglioni L. Prevalence of chronic diseases and multimorbidity among the elderly population in Sweden. American Journal of Public Health 2008;98:1198-200.

[5] Boyd C, Fortin M. Future of multimorbidity research: how should understanding of multimorbidity inform health system design? Public Health Reviews 2010;32:451-74.

[6] Marengoni A, Angleman S, Melis R, Mangialasche F, Karp A, Garmen A, et al. Aging with multimorbidity: a systematic review of the literature. Ageing Research Reviews 2011;10:430-9.

[7] Feinstein AR. The pre-therapeutic classification of co-morbidity in chronic disease. Journal of Chronic Disease 1970;23:455-68.

[8] Vogeli C, Shields AE, Lee TA, Gibson TB, Marder WD, Weiss KB, et al. Multiple chronic conditions: prevalence, health consequences, and implications for quality, care management, and costs. Journal of General Internal Medicine 2007;22(Suppl. 3):391-5.

[9] Van den Akker M, Buntinx F, Metsemakers JF, Roos S, Knottnerus JA. Multimorbidity in general practice: prevalence, incidence, and determinants of co-occurring chronic and recurrent diseases. Journal of Clinical Epidemiology 1998;51:367-75.

[10] Fortin M, Bravo G, Hudon C, Lapointe L, Almirall J, Dubois MF, et al. Relationship between multimorbidity and health-related quality of life of patients in primary care. Quality of Life Research 2006;15:83-91.

[11] Wright K, Hazelett S, Jarjoura D, Allen K. The AD-LIFE trial: working to integrate medical and psychosocial care management models. Home Healthcare Nurse 2007;25:308-14.

[12] Clarfield AM, Bergman $\mathrm{H}$, Kane R. Fragmentation of care for frail older people-an international problem. Experience from three countries: Israel, Canada, and the United States. Journal of the American Geriatrics Society 2001;49:1714-21.

[13] Greß S, Baan CA, Clanan M, Dedeu T, Groenewegen P, Howson H, et al. Co-ordination and management of chronic conditions in Europe: the role of primary care-position paper of the European forum for primary care. Quality in Primary Care 2009;17:75-86.

[14] Fortin M, Soubhi H, Hudon C, Bayliss EA, Van den Akker M. Multimorbidity's many challenges. British Medical Journal 2007;334: 1016-7.

[15] Westert GP, Satariano WA, Schellevis FG, Van Den Bos GAM. Patterns of comorbidity and the use of health services in the Dutch population. European Journal of Public Health 2001;11:365-72.

[16] Versnel N, Welschen LM, Baan CA, Nijpels G, Schellevis FG. The effectiveness of case management for comorbid diabetes type 2 patients; the CasCo study. Design of a randomized controlled trial. BMC Family Practice 2011;12, http://dx.doi.org/10.1186/4712296-12-68.

[17] Boult C, Green AF, Boult LB, Pacala JT, Snyder C, Leff B. Successful models of comprehensive care for older adults with chronic conditions: evidence for the institute of medicine's "retooling for an Aging America" report. Journal of the American Geriatrics Society 2009;57:2328-37.

[18] Wagner EH, Bennett SM, Austin BT, Greene SM, Schaefer JK, Vonkorff M. Finding common ground: patient-centeredness and evidencebased chronic illness care. Journal of Alternative and Complementary Medicine 2005;11(Suppl. 1):S7-15.

[19] Mattke S, Seid M, Ma S. Evidence for the effect of disease management: is $\$ 1$ billion a year a good investment? American Journal of Managed Care 2007;13:670-6.

[20] Boult C, Wieland GD. Comprehensive primary care for older patients with multiple chronic conditions: "Nobody rushes you through". JAMA 2010;304:1936-43.

[21] Eklund K, Wilhelmson K. Outcomes of coordinated and integrated interventions targeting frail elderly people: a systematic review of randomised controlled trials. Health and Social Care in the Community 2009;17:447-58.

[22] Latour CH, van der Windt DA, de Jonge P, Riphagen II, de Vos R, Huyse FJ, et al. Nurse-led case management for ambulatory complex patients in general health care: a systematic review. Journal of Psychosomatic Research 2007;62:385-95.

[23] Oeseburg B, Wynia K, Middel B, Reijneveld SA. Effects of case management for frail older people or those with chronic illness: A systematic review. Nursing Research 2009;58:201-10. 
Bruin, S.R. de, Versnel, N., Lemmens, L.C., Molema, C.C.M., Schellevis, F.G., Nijpels, G., Baan C.A. Comprehensive care programs for patients with multiple chronic conditions: a systematic literature review. Health Policy: 2012, 107(2-3), 108-145

[24] Peikes D, Chen A, Schore J, Brown R. Effects of care coordination on hospitalization, quality of care, and health care expenditures among Medicare beneficiaries: 15 randomized trials. JAMA 2009;301:603-18.

[25] Low LF, Yap M, Brodaty H. A systematic review of different models of home and community care services for older persons. BMC Health Services Research 2011;11:93.

[26] Norris SL, Nichols PJ, Caspersen CJ, Glasgow RE, Engelgau MM, Jack L, et al. The effectiveness of disease and case management for people with diabetes. A systematic review. American Journal of Preventive Medicine 2002;22:15-38.

[27] De Bruin SR, Heijink R, Lemmens L, Struijs JN, Baan CA. Impact of disease management programs on healthcare expenditures for patients with diabetes, depression, heart failure or chronic obstructive pulmonary disease: a systematic review of the literature. Health Policy 2011;101:105-21.

[28] Lemmens K, Lemmens L, Boom J, Drewes H, Meeuwissen J, Steuten L, et al. Chronic care management for patients with COPD: a critical review of available evidence. Journal of Evaluation in Clinical Practice 2011, http://dx.doi.org/10.1111/j.1365-2753.2011.01805.x.

[29] Tsai AC, Morton SC, Mangione CM, Keeler EB. A meta-analysis of interventions to improve care for chronic illnesses. American Journal of Managed Care 2005;11:478-88.

[30] Zwar N, Harris M, Griffiths R, Roland M, Dennis S, Powell Davis G, et al. APHCRI stream four: a systematic review of chronic disease management. Canberra: Australian Primary Health Care Research Institute (APHCRI); 2006.

[31] Adams SG, Smith PK, Allan PF, Anzueto A, Pugh JA, Cornell JE. Systematic review of the chronic care model in chronic obstructive pulmonary disease prevention and management. Archives of Internal Medicine 2007;167:551-61.

[32] Wagner EH, Austin BT, Davis C, Hindmarsh M, Schaefer J, Bonomi A. Improving chronic illness care: translating evidence into action. Health Affairs (Millwood) 2001;20:6478.

[33] Wagner EH. The role of patient care teams in chronic disease management. British Medical Journal 2000;320:569-72.

[34] Organisation for Economic Co-operation and Development. OECD Health Data 2009. Paris: OECD; 2009.

[35] Van Tulder M, Furlan A, Bombardier C, Bouter L. Updated method guidelines for systematic reviews in the cochrane collaboration back review group. Spine (Phila Pa 1976) 2003;28:1290-9.

[36] Verhagen AP, de Vet HC, de Bie RA, Kessels AG, Boers M, Bouter LM, et al. The Delphi list: a criteria list for quality assessment of randomized clinical trials for conducting systematic reviews developed by Delphi consensus. Journal of Clinical Epidemiology 1998;51:1235-41.

[37] Proper KI, Singh AS, van Mechelen W, Chinapaw MJ. Sedentary behaviors and health outcomes among adults: a systematic review of prospective studies. American Journal of Preventive Medicine 2011;40:174-82.

[38] Hoogendoorn WE, van Poppel MN, Bongers PM, Koes BW, Bouter LM. Systematic review of psychosocial factors at work and private life as risk factors for back pain. Spine (Phila Pa 1976) 2000;25:2114-25.

[39] Singh AS, Mulder C, Twisk J, Van Mechelen W, Chinapaw MJ. Tracking of childhood overweight into adulthood: a systematic review of the literature. Obesity reviews 2008;9:474-88.

[40] Kobb R, Hoffman N, Lodge R, Kline S. Enhancing elder chronic care through technology and care coordination: report from a pilot. Telemedicine Journal and e-Health 2003;9:18995.

[41] Liddy C, Dusseault JJ, Dahrouge S, Hogg W, Lemelin J, Humbert J. Telehomecare for patients with multiple chronic illnesses: pilot study. Canadian Family Physician 2008;54:58-65.

[42] Procter S, Single A. Home telehealthcare: findings from a pilot study in North-east London. The British Journal of Healthcare Computing \& Information Management 2006;23:10-3.

[43] Béland F, Bergman H, Lebel P, Dallaire L, Fletcher J, Contandriopoulos AP, et al. Integrated services for frail elders (SIPA): a trial of a model for Canada. Canadian Journal on Aging 2006;25:5-42. 
Bruin, S.R. de, Versnel, N., Lemmens, L.C., Molema, C.C.M., Schellevis, F.G., Nijpels, G., Baan, C.A. Comprehensive care programs for patients with multiple chronic conditions: a systematic literature review. Health Policy: 2012, 107(2-3), 108-145

[44] Boyd C, Reider L, Frey K, Scharfstein D, Leff B, Wolff J, et al. The effects of guided care on the perceived quality of health care for multi-morbid older persons: 18-month outcomes from a clusterrandomized controlled trial. Journal of General Internal Medicine 2010;25:235-42.

[45] Boult C, Reider L, Frey K, Leff B, Boyd CM, Wolff JL, et al. Early effects of "Guided Care" on the quality of health care for multimorbid older persons: a cluster-randomized controlled trial. Journals of Gerontology Series A-Biological Sciences \& Medical Sciences 2008;63:321-7.

[46] Leff B, Reider L, Frick KD, Scharfstein DO, Boyd CM, Frey K, et al. Guided care and the cost of complex healthcare: a preliminary report. The American Journal of Managed Care 2009;15:555-9.

[47] Wolff JL, Giovannetti ER, Boyd CM, Reider L, Palmer S, Scharfstein D, et al. Effects of guided care on family caregivers. The Gerontologist 2010;50:459-70.

[48] Boyd C, Shadmi E, Conwell LJ, Griswold M, Leff B, Brager R, et al. A pilot test of the effect of guided care on the quality of primary care experiences for multimorbid older adults. Journal of General Internal Medicine 2008;23:536-42.

[49] Sylvia ML, Griswold M, Dunbar L, Boyd CM, Park M, Boult C. Guided care: cost and utilization outcomes in a pilot study. Disease Management 2008;11:29-36.

[50] Coleman EA, Grothaus LC, Sandhu N, Wagner EH. Chronic care clinics: a randomized controlled trial of a new model of primary care for frail older adults. Journal of the American Geriatrics Society 1999;47:775-83.

[51] Counsell SR, Callahan CM, Clark DO, Tu W, Buttar AB, Stump TE, et al. Geriatric care management for low-income seniors: a randomized controlled trial. JAMA 2007;298:262333.

[52] Counsell SR, Callahan CM, Tu W, Stump TE, Arling GW. Cost analysis of the Geriatric Resources for Assessment and Care of Elders care management intervention. Journal of the American Geriatrics Society 2009;57:1420-6.

[53] Dorr DA, Wilcox A, Burns L, Brunker CP, Narus SP, Clayton PD. Implementing a multidisease chronic care model in primary care using people and technology. Disease Management 2006;9:1-15.

[54] Dorr DA, Wilcox AB, Brunker CP, Burdon RE, Donnelly SM. The effect of technologysupported, multidisease care management on the mortality and hospitalization of seniors. Journal of the American Geriatrics Society 2008;56:2195-202.

[55] Duke C. The frail elderly community-based case management project. Geriatric Nursing 2005;26:122-7.

[56] Leveille SG, Wagner EH, Davis C, Grothaus L, Wallace J, LoGerfo M, et al. Preventing disability and managing chronic illness in frail older adults: a randomized trial of a community-based partnership with primary care. Journal of the American Geriatrics Society 1998;46:1191-8.

[57] Littleford A, Kralik D. Making a difference through integrated community care for older people. Journal of Nursing and Healthcare of Chronic Illness 2010:178-86.

[58] Markle-Reid M, Weir R, Browne G, Roberts J, Gafni A, Henderson S. Health promotion for frail older home care clients. Journal of Advanced Nursing 2006;54:381-95.

[59] Marsteller JA, Hsu YJ, Reider L, Frey K, Wolff J, Boyd C, et al. Physician satisfaction with chronic care processes: a cluster-randomized trial of guided care. Annals of Family Medicine 2010;8:308-15.

[60] Mitton C, O'Neil D, Simpson L, Hoppins Y, Harcus S. Nurse-Physician Collaborative Partnership: a rural model for the chronically ill. Canadian Journal of Rural Medicine 2007;12:208-16.

[61] Rubenstein LZ, Alessi CA, Josephson KR, Trinidad Hoyl M, Harker JO, Pietruszka FM. A randomized trial of a screening, case finding, and referral system for older veterans in primary care. Journal of the American Geriatrics Society 2007;55:166-74.

[62] Sorrento TA, Casselman MB, Noonan J. A consultant pharmacist's role on a geriatric assessment service. The Consultant Pharmacist 2007;22:935-43.

[63] Anonymous. DM for complex patients tackles hospital utilization in a big way. Disease Management Advisor 2003;9:99-101.

[64] Krause CM, Jones CS, Joyce S, Kuhn ME, Curtin K, Murphy LP, et al. The impact of a multidisciplinary, integrated approach on improving the health and quality of care for 
Bruin, S.R. de, Versnel, N., Lemmens, L.C., Molema, C.C.M., Schellevis, F.G., Nijpels, G., Baan C.A. Comprehensive care programs for patients with multiple chronic conditions: a systematic literature review. Health Policy: 2012, 107(2-3), 108-145

individuals dealing with multiple chronic conditions. American Journal of Orthopsychiatry 2006;76:109-14.

[65] Brand CA, Jones CT, Lowe AJ, Nielsen DA, Roberts CA, King BL, et al. A transitional care service for elderly chronic disease patients at risk of readmission. Australian Health Review 2004;28:275-84.

[66] Burns R, Nichols LO, Graney MJ, Cloar FT. Impact of continued geriatric outpatient management on health outcomes of older veterans. Archives of Internal Medicine 1995;155:1313-8.

[67] Courtney M, Edwards H, Chang A, Parker A, Finlayson K, Hamilton K. Fewer emergency readmissions and better quality of life for older adults at risk of hospital readmission: a randomized controlled trial to determine the effectiveness of a 24-week exercise and telephone follow-up program. Journal of the American Geriatrics Society 2009;57:395-402.

[68] Saltvedt I, Jordhoy M, Opdahl Mo ES, Fayers P, Kaasa S, Sletvold O. Randomised trial of in-hospital geriatric intervention: impact on function and morale. Gerontology 2006;52:223-30.

[69] Saltvedt I, Mo ES, Fayers P, Kaasa S, Sletvold O. Reduced mortality in treating acutely sick, frail older patients in a geriatric evaluation and management unit. A prospective randomized trial. Journal of the American Geriatrics Society 2002;50:792-8.

[70] Schmader KE, Hanlon JT, Pieper CF, Sloane R, Ruby CM, Twersky J, et al. Effects of geriatric evaluation and management on adverse drug reactions and suboptimal prescribing in the frail elderly. The American Journal of Medicine 2004;116:394-401.

[71] Tibaldi V, Aimonino N, Ponzetto M, Stasi MF, Amati D, Raspo S, et al. A randomized controlled trial of a home hospital intervention for frail elderly demented patients: behavioral disturbances and caregiver's stress. Archives of Gerontology and Geriatrics Suppl 2004: 431-6.

[72] Daly BJ, Douglas SL, Kelley CG, O'Toole E, Montenegro H. Trial of a disease management program to reduce hospital readmissions of the chronically critically ill. Chest 2005;128:507-17.

[73] Douglas SL, Daly BJ, Kelley CG, O'Toole E, Montenegro H. Chronically critically ill patients: health-related quality of life and resource use after a disease management intervention. American Journal of Critical Care 2007;16:447-57.

[74] Naylor MD, Brooten DA, Campbell RL, Maislin G, McCauley KM, Schwartz JS. Transitional care of older adults hospitalized with heart failure: a randomized, controlled trial. Journal of the American Geriatrics Society 2004;52:675-84.

[75] Zhang NJ, Wan TT, Rossiter LF, Murawski MM, Patel UB. Evaluation of chronic disease management on outcomes and cost of care for Medicaid beneficiaries. Health Policy 2008;86: 345-54.

[76] Taylor CB, Miller NH, Reilly KR, Greenwald G, Cunning D, Deeter A, et al. Evaluation of a nurse-care management system to improve outcomes in patients with complicated diabetes. Diabetes Care 2003;26:1058-63.

[77] Elzen H, Slaets JP, Snijders TA, Steverink N. Evaluation of the chronic disease selfmanagement program (CDSMP) among chronically ill older people in the Netherlands. Social Science \& Medicine 2007;64:1832-41.

[78] Rose MA, Arenson C, Harrod P, Salkey R, Santana A, Diamond J. Evaluation of the Chronic Disease Self-Management Program with low-income, urban, African American older adults. Journal of Community Health Nursing 2008;25:193-202.

[79] Chumbler NR, Mann WC, Wu S, Schmid A, Kobb R. The association of home-telehealth use and care coordination with improvement of functional and cognitive functioning in frail elderly men. Telemedicine Journal and e-Health 2004;10:129-37.

[80] Folstein MF, Folstein SE, McHugh PR. "Mini-mental state". A practical method for grading the cognitive state of patients for the clinician. Journal of Psychiatric Research 1975;12:189-98.

[81] Keith RA, Granger CV, Hamilton BB, Sherwin FS. The functional independence measure: a new tool for rehabilitation. Advanced Clinical Rehabilitation 1987;1:6-18.

[82] Ofman JJ, Badamgarav E, Henning JM, Knight K, Gano Jr AD, Levan RK, et al. Does disease management improve clinical and economic outcomes in patients with chronic diseases? A systematic review. American Journal of Medicine 2004;117:182-92. 
Bruin, S.R. de, Versnel, N., Lemmens, L.C., Molema, C.C.M., Schellevis, F.G., Nijpels, G., Baan C.A. Comprehensive care programs for patients with multiple chronic conditions: a systematic literature review. Health Policy: 2012, 107(2-3), 108-145

[83] Singh D. How can chronic disease management programmes operate across care settings and providers? Birmingham: World Health Organization; 2008.

[84] Weingarten SR, Henning JM, Badamgarav E, Knight K, Hasselblad V, Gano Jr A, et al. Interventions used in disease management programmes for patients with chronic illnesswhich ones work? Meta-analysis of published reports. British Medical Journal 2002;325:925.

[85] Goetzel RZ, Ozminkowski RJ, Villagra VG, Duffy J. Return on investment in disease management: a review. Health Care Financing Review 2005;26:1-19.

[86] De Bruin SR, Baan CA, Struijs JN. Pay-for-performance in disease management: a systematic review of the literature. BMC Health Services Research 2011;11, http://dx.doi.org/10.1186/472-6963-11-272.

[87] Allen KR, Hazelett SE, Jarjoura D, Wright K, Fosnight SM, Kropp DJ, et al. The after Discharge Care Management of Low Income Frail Elderly (AD-LIFE) randomized trial: theoretical framework and study design. Population Health Management 2011;14:137-42.

[88] Coleman K, Austin BT, Brach C, Wagner EH. Evidence on the Chronic Care Model in the new millennium. Health Affairs (Millwood) 2009;28:75-85.

[89] Steuten LMG, Vrijhoef HJM, Van Merode GG, Severens JL, Spreeuwenberg C. The Health Technology Assessment-Disease Management instrument reliably measured methodologic quality of health technology assessments of disease management. Journal of Clinical Epidemiology 2004;57:881-8.

[90] Drewes H, Steuten L, Lemmens L, Baan C, Boshuizen H, Elissen A, et al. The effectiveness of chronic care management for heart failure: meta-regression analysis to explain the heterogeneity in outcomes. Health Services Research 2012, http://dx.doi.org/10.1111/j.1475-6773.2012.01396.x.

[91] Peytremann-Bridevaux I, Staeger P, Bridevaux PO, Ghali WA, Burnand B. Effectiveness of chronic obstructive pulmonary diseasemanagement programs: systematic review and meta-analysis. The American Journal of Medicine 2008;121, 433-43 e4.

[92] Seto E. Cost comparison between telemonitoring and usual care of heart failure: a systematic review. Telemedicine Journal and e-Health

2008;14:679-86.

[93] Lemmens K, Nieboer A, Huijsman R. A systematic review of integrated use of disease management interventions in asthma and COPD. Respiratory Medicine 2009;103:670-91.

[94] Solberg LI, Crain AL, Sperl-Hillen JM, Hroscikoski MC, Engebretson KI, O'Connor PJ. Care quality and implementation of the chronic care model: a quantitative study. Annals of Family Medicine

2006;4:310-6.

[95] Baumgarten M, Lebel P, Laprise H, Leclerc C, Quinn C. Adult day care for the frail elderly: outcomes, satisfaction, and cost. Journal of Aging and Health 2002;14:237-59.

[96] Zank S, Schacke C. Evaluation of geriatric day care units: effects on patients and caregivers. The Journals of Gerontology Series B: Psychological Sciences and Social Sciences 2002;57:P348-57.

[97] Rockwood K, Howlett S, Stadnyk K, Carver D, Powell C, Stolee P. Responsiveness of goal attainment scaling in a randomized controlled trial of comprehensive geriatric assessment. Journal of Clinical Epidemiology 2003;56:736-43.

[98] Bouwens SF, van Heugten CM, Verhey FR. Review of goal attainment scaling as a useful outcome measure in psychogeriatric patients with cognitive disorders. Dementia and Geriatric Cognitive Disorders 2008;26:528-40.

[99] Luppa M, Luck T, Brähler E, König HH, Riedel-Heller SG. Prediction of institutionalisation in dementia: a systematic review. Dementia and Geriatric Cognitive Disorders 2008;26:65-78. 
Bruin, S.R. de, Versnel, N., Lemmens, L.C., Molema, C.C.M., Schellevis, F.G., Nijpels, G., Baan, C.A. Comprehensive care programs for patients with multiple chronic conditions: a systematic literature review. Health Policy: 2012, 107(2-3), 108-145

\section{TABLES}

Fig. 1. Flow diagram of literature screening process.

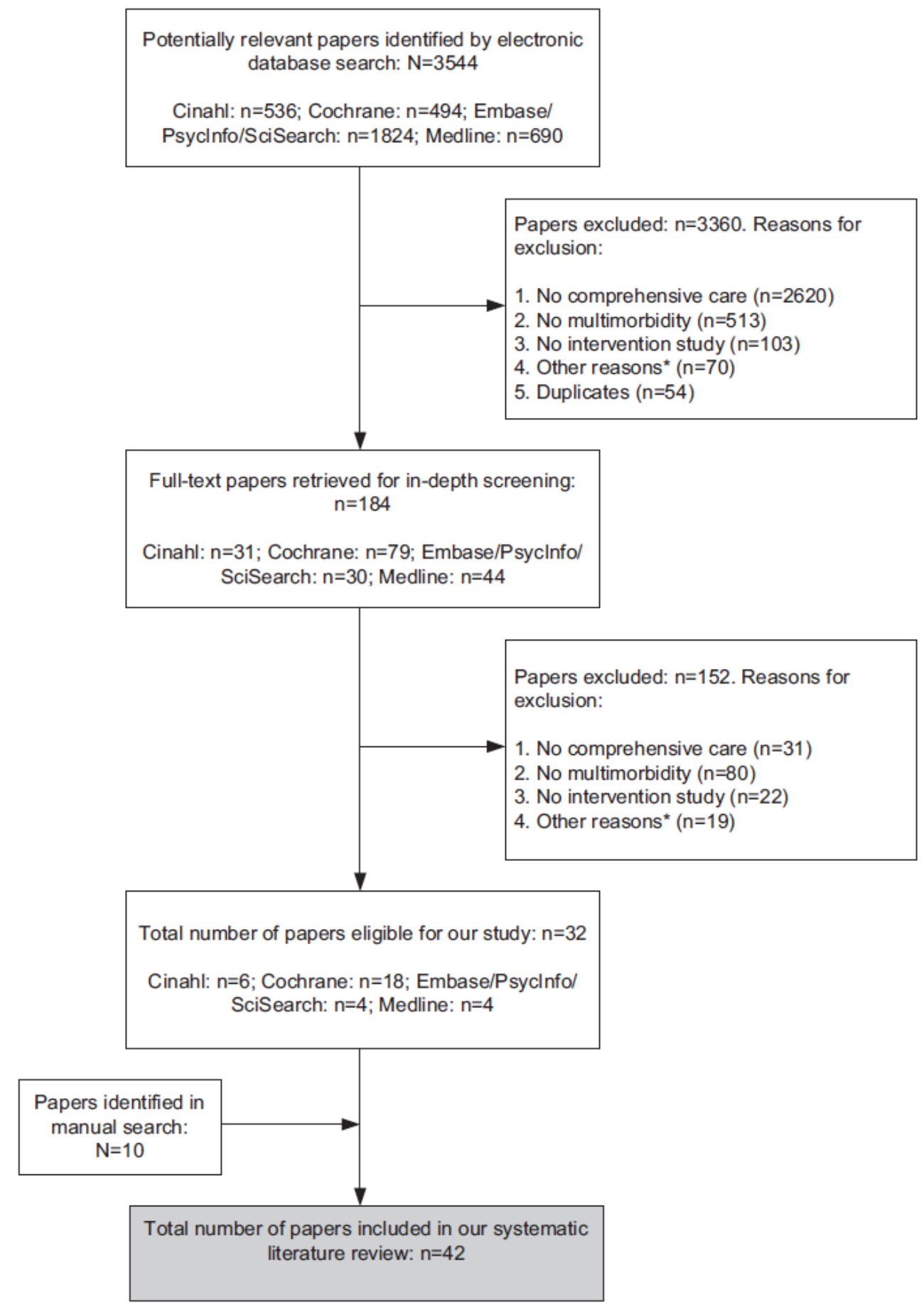

*e.g. papers were not written in English, papers could not be retrieved, identified documents were non-scientific papers, papers described the design of an intervention study only. 
Bruin, S.R. de, Versnel, N., Lemmens, L.C., Molema, C.C.M., Schellevis, F.G., Nijpels, G., Baan, C.A. Comprehensive care programs for patients with multiple chronic conditions: a systematic literature review. Health Policy: 2012, 107(2-3), 108-145

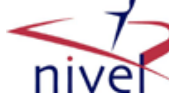

\begin{tabular}{|c|c|c|c|c|c|c|c|}
\hline Author (year) & $\begin{array}{l}\text { Study design } \\
(N)^{3}\end{array}$ & $\begin{array}{l}\text { Length of } \\
\text { follow-up } \\
\text { (months) }\end{array}$ & $\begin{array}{l}\text { Target } \\
\text { population }\end{array}$ & Setting & Contents of comprehensive care program $c$ & Usual care $^{d}$ & Outcomese \\
\hline Anonymous [63] & $\begin{array}{l}\text { Pretest-posttest } \\
\text { design (pilot) } \\
(N=60)\end{array}$ & 12 & $\begin{array}{l}\text { Highly complex } \\
\text { patients with } \\
\text { about } 7 \\
\text { diagnoses and } \\
\text { high healthcare } \\
\text { consumption. }\end{array}$ & $\begin{array}{l}\text { Hospital care, } \\
\text { community } \\
\text { care, and home } \\
\text { care in the USA }\end{array}$ & 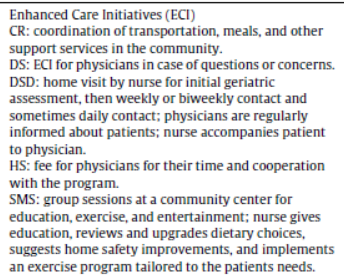 & N.A. & $\begin{array}{l}\text { Patients } \\
\text { Inpatient and outpatient hospital } \\
\text { expenditures decreased considerably (i.e } \\
\text { 2265.085) after implementation of the } \\
\text { program (change over time was not } \\
\text { tested for significance). }\end{array}$ \\
\hline Béland et al. [43] & $\operatorname{RCT}(N=1309)$ & 22 & $\begin{array}{l}\text { Frail older } \\
\text { people aged } \geq 65 \\
\text { years with } \\
\text { functional } \\
\text { disabilities and } \\
\text { complex service } \\
\text { needs and their } \\
\text { informal } \\
\text { caregivers. }\end{array}$ & $\begin{array}{l}\text { Community, } \\
\text { primary, and } \\
\text { hospital care by } \\
\text { Integrated } \\
\text { Services for Frail } \\
\text { Elders (SIPA) } \\
\text { sites (located } \\
\text { within local } \\
\text { community } \\
\text { service centers) } \\
\text { in Canada }\end{array}$ & 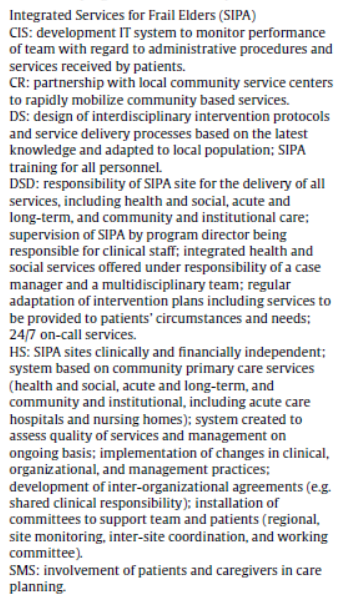 & $\begin{array}{l}\text { Usual services } \\
\text { available to frail } \\
\text { older people. }\end{array}$ & 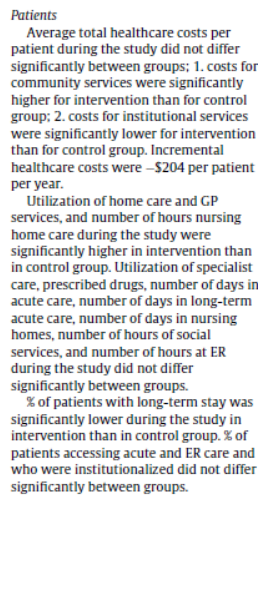 \\
\hline
\end{tabular}

\begin{tabular}{|c|c|c|c|c|c|c|c|}
\hline Author (year) & $\begin{array}{l}\text { Study design } \\
(N)^{\mathrm{a}}\end{array}$ & $\begin{array}{l}\text { Length of } \\
\text { follow-up } \\
\text { (months }\end{array}$ & $\begin{array}{l}\text { Target } \\
\text { population }\end{array}$ & Setting & Contents of comprehensive care program ${ }^{C}$ & Usual care ${ }^{d}$ & Outcomese $^{e}$ \\
\hline $\begin{array}{l}\text { Boult et al al [45]; } \\
\text { Boyd et al. } \\
\text { [44]; Leff et al. } \\
\text { [46,l, and } \\
\text { Wolff et al. } \\
\text { [47]] }\end{array}$ & $\begin{array}{l}\text { CRCT }(N=904 \\
\text { patients; } N=308 \\
\text { informal } \\
\text { caregivers; } \\
N=33 \\
\text { professional } \\
\text { caregivers) }\end{array}$ & $\begin{array}{l}8 \text { (healthcare } \\
\text { costs and } \\
\text { utilization), } 12 \\
\text { (professional } \\
\text { caregivers), and } \\
18 \text { (other } \\
\text { patient } \\
\text { outcomes and } \\
\text { informal } \\
\text { caregivers) }\end{array}$ & $\begin{array}{l}\text { Multimorbid } \\
\text { people aged } \geq 65 \\
\text { years with high } \\
\text { probability of } \\
\text { using health } \\
\text { services } \\
\text { intensively/at } \\
\text { high risk for } \\
\text { incurring high } \\
\text { healthcare costs } \\
\text { in the coming } \\
\text { year. }\end{array}$ & $\begin{array}{l}\text { Primary care by } \\
8 \text { primary care } \\
\text { practices in the } \\
\text { USA }\end{array}$ & 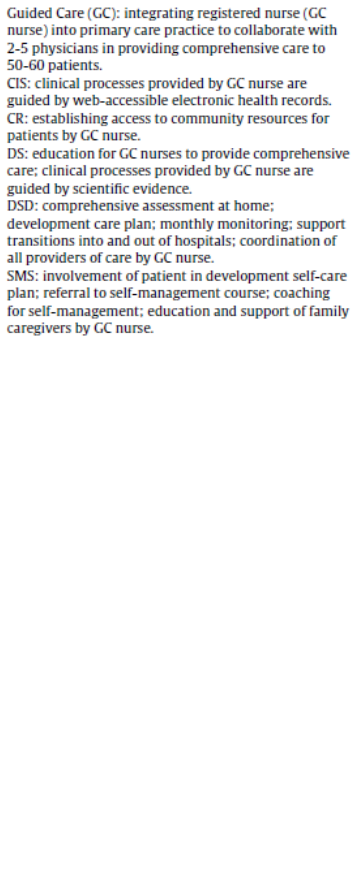 & N.R. & 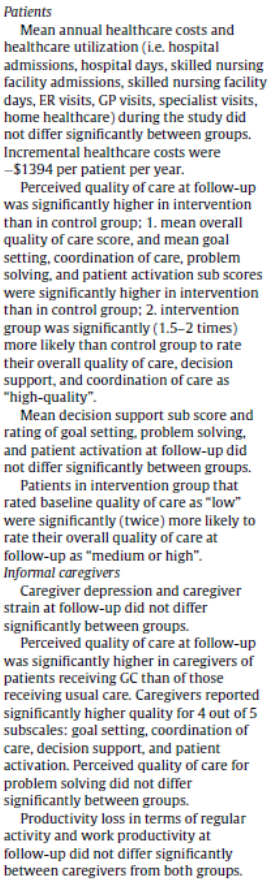 \\
\hline
\end{tabular}


Bruin, S.R. de, Versnel, N., Lemmens, L.C., Molema, C.C.M., Schellevis, F.G., Nijpels, G., Baan, C.A. Comprehensive care programs for patients with multiple chronic conditions: a systematic literature review. Health Policy: 2012, 107(2-3), 108-145

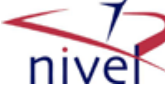

\begin{tabular}{|c|c|c|c|c|c|c|c|}
\hline $\begin{array}{l}\text { Boyd et al. [48] } \\
\text { and Sylvia } \\
\text { et al. [49] }\end{array}$ & $\begin{array}{l}\mathrm{CCT} \text { (pilot) }) \\
(N=150)\end{array}$ & 6 & $\begin{array}{l}\text { Multimorbid } \\
\text { people aged } \geq 65 \\
\text { years and with } \\
\text { high probability } \\
\text { of using health } \\
\text { services } \\
\text { intensively in } \\
\text { the coming year. }\end{array}$ & $\begin{array}{l}\text { Primary care by } \\
1 \text { primary care } \\
\text { practice in the } \\
\text { USA }\end{array}$ & Guided Care (see Boult et al. [45]) & N.R. & $\begin{array}{l}\text { between physicians from both groups. } \\
\text { Patients } \\
\text { Healthcare costs and healthcare } \\
\text { utilization (i.e. hospital admissions, hospital } \\
\text { days, ER visits, primary care visits did not } \\
\text { differ significantly between groups during } \\
\text { the study. Incremental healthcare costs } \\
\text { were - } \$ 3089 \text { per patient per year. } \\
\text { Change in quality of patient-physician } \\
\text { commmnnication over time differed } \\
\text { significantly between intervention group } \\
\text { and control group: qualitity of } \\
\text { patient-physician communication } \\
\text { significantly improved in intervention } \\
\text { group. } \\
\text { Change in physician's comprehensive } \\
\text { knowledge of patient, quality of integration } \\
\text { of care, interpersonal treatment, and trust in } \\
\text { physician over time did not differ } \\
\text { significantly between groups. }\end{array}$ \\
\hline Brand et al. [65] & $\mathrm{CCT}(\mathrm{N}=166)$ & 3 and 6 & $\begin{array}{l}\text { General medical } \\
\text { patients aged } \\
\geq 65 \text { years with } \\
\text { an inpatient stay } \\
\text { of }>24 \text { hours and } \\
\text { with either a } \\
\text { history of } \\
\text { readmissions to } \\
\text { acutec care, } \\
\text { multiple } \\
\text { medical } \\
\text { co-morbidities, } \\
\text { or admission, } \\
\text { diagnosis of } \\
\text { CHF. }\end{array}$ & $\begin{array}{l}\text { Hospital care by } \\
1 \text { tertiary } \\
\text { teaching } \\
\text { hospital in } \\
\text { Australia }\end{array}$ & 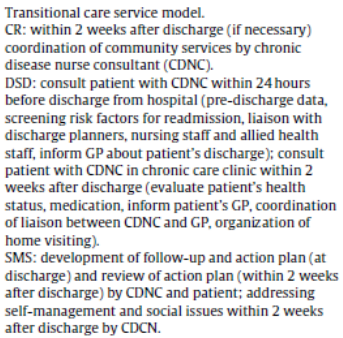 & $\begin{array}{l}\text { Medical, nursing } \\
\text { and allied health } \\
\text { intervention } \\
\text { consistent with the } \\
\text { patient's siagnosis } \\
\text { and resources } \\
\text { available on the } \\
\text { general medical } \\
\text { wards. Also } \\
\text { includses discharge } \\
\text { planning by the } \\
\text { multidisciplinary } \\
\text { team and could } \\
\text { include } \\
\text { out-patient } \\
\text { follow-up. }\end{array}$ & $\begin{array}{l}\text { Patients } \\
\text { GP visits and quality of life at 3-month } \\
\text { follow-up did not differ significantly } \\
\text { between groups. } \\
\text { ER Risists and readmission rate at } 6 \text {-month } \\
\text { follow-up did not differ significantly } \\
\text { between groups. }\end{array}$ \\
\hline
\end{tabular}

\begin{tabular}{|c|c|c|c|c|c|c|c|}
\hline Author (year) & $\begin{array}{l}\text { Study design } \\
(N)^{\mathrm{a}}\end{array}$ & $\begin{array}{l}\text { Length of } \\
\text { follow-up } \\
(\text { months })^{b}\end{array}$ & $\begin{array}{l}\text { Target } \\
\text { population }\end{array}$ & Setting & Contents of comprehensive care program ${ }^{c}$ & Usual cared $^{d}$ & Outcomes $^{e}$ \\
\hline Burns et al. [66] & $\operatorname{RCT}(N=130)$ & 12 & $\begin{array}{l}\text { Hospitalized } \\
\text { veterans aged } \\
\geq 65 \text { years } \\
\text { diagnosed with } \\
\geq 1 \text { ADLLdeficit, } \\
\geq 2 \text { chronic } \\
\text { medical } \\
\text { conditions, } \geq 2 \\
\text { acute } \\
\text { hospitalizations } \\
\text { in previous year, } \\
\text { or taking } \geq 6 \\
\text { scheduled } \\
\text { prescription } \\
\text { drugs. }\end{array}$ & $\begin{array}{l}\text { Hospital care by } \\
\text { Veterans Affairs } \\
\text { medical center } \\
\text { in the USA. }\end{array}$ & $\begin{array}{l}\text { Outpatient Geriatric Evaluation and } \\
\text { Management (GEM) clinic } \\
\text { DS: participatation of interdisciplinary team in } \\
\text { extensive team training and development. } \\
\text { DSD: interdisciplinary primary care team } \\
\text { (geriatric physicians, nurse practititioner, } \\
\text { social worker, psychologists, clinical } \\
\text { pharmacistst that focused on evaluation and } \\
\text { long-term management or primary care } \\
\text { (particiular focus on special elderly } \\
\text { problems); review by team of patients' and } \\
\text { caregivers' resources and needs: initial } \\
\text { 2-hour assessment was performed by entire } \\
\text { team; team developed goals, interventions, } \\
\text { and treatment and provided continuous } \\
\text { individualized follow-up and aftercare after } \\
\text { discharge (e.g. short-term hospital admission, } \\
\text { routine care in clinic by relevant healthcare } \\
\text { providers with telephone follow-up). }\end{array}$ & $\begin{array}{l}\text { After hospital } \\
\text { discharge } \\
\text { inpatient } \\
\text { treatment team } \\
\text { referred patients } \\
\text { back to previous } \\
\text { provider(s) or to } \\
\text { new provider(s) } \\
\text { if necessary. } \\
\text { Outpatient care } \\
\text { was provided in } \\
\text { ambulatory care } \\
\text { clinics of the VA } \\
\text { medical center } \\
\text { or by local } \\
\text { physicians in } \\
\text { the community. }\end{array}$ & 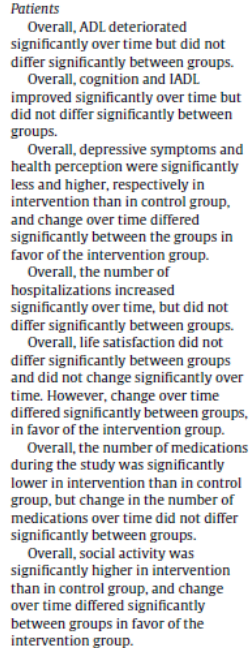 \\
\hline
\end{tabular}


Bruin, S.R. de, Versnel, N., Lemmens, L.C., Molema, C.C.M., Schellevis, F.G., Nijpels, G., Baan, C.A. Comprehensive care programs for patients with multiple chronic conditions: a systematic literature review. Health Policy: 2012, 107(2-3), 108-145

\begin{tabular}{|c|c|c|c|c|c|c|c|}
\hline $\begin{array}{l}\text { Chumbler et al. } \\
\text { [79] }\end{array}$ & $\begin{array}{l}\text { Case control } \\
\text { design in which } \\
\text { subjects } \\
\text { receiving } \\
\text { comprehensive } \\
\text { care were } \\
\text { compared with } \\
\text { subjects from } \\
\text { another } \\
\text { longitudinal } \\
\text { study }(N=226)\end{array}$ & 12 & $\begin{array}{l}\text { Veterans with, } \\
\text { hypertension, } \\
\text { congestive heart } \\
\text { failure, } \\
\text { respiratory } \\
\text { disease, or } \\
\text { diabetes, who } \\
\text { had } \geq 2 \text { ED visits, } \\
\text { hospitalizations, } \\
\text { or unscheduled } \\
\text { walk-in visits in } \\
\text { the previous } 12 \\
\text { months, and/or } \\
\text { obtained care } \\
\text { costing } \\
\geq \$ 25,000 \text {. }\end{array}$ & $\begin{array}{l}\text { Home care by } \\
\text { Veterans Health } \\
\text { System in the } \\
\text { uSA }\end{array}$ & 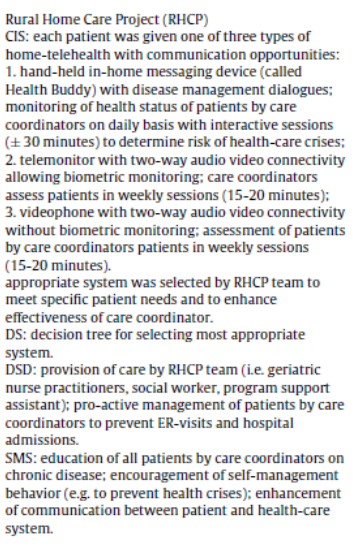 & $\begin{array}{l}\text { Disabled elders } \\
\geq 60 \text { years, with } \geq 1 \\
\text { (1)ADLL limitation } \\
\text { recruited from } \\
\text { another } \\
\text { longitudinal study. }\end{array}$ & $\begin{array}{l}\text { Patients } \\
\text { With the exception of change in } \\
\text { cognitive functioning measured with the } \\
\text { MMEE change over time in all outtomes } \\
\text { differed significantly between the groups, } \\
\text { in favor of the intervention group. } \\
\text { IADL and cognitive functioning } \\
\text { measured on FiM cognitivive subscale } \\
\text { improved significantly over time in } \\
\text { intervention group and significantly } \\
\text { deteriorated in the control group. ADL, } \\
\text { cognitive functioning measured. with the } \\
\text { MMSE, and independent functioning } \\
\text { significantly improved in the intervention } \\
\text { group and remained stable in the control } \\
\text { group. }\end{array}$ \\
\hline $\begin{array}{l}\text { Coleman et al. } \\
\text { [50] }\end{array}$ & $\operatorname{RCT}(N=169)$ & 24 & $\begin{array}{l}\text { Frail older adults } \\
\text { aged } \geq 6 \text { y years } \\
\text { at high risk for } \\
\text { hospitalization } \\
\text { and functional } \\
\text { decline in the } \\
\text { subsequent } 4 \\
\text { years. }\end{array}$ & $\begin{array}{l}\text { Primary care by } \\
9 \text { primary care } \\
\text { physician } \\
\text { practices in the } \\
\text { USA }\end{array}$ & $\begin{array}{l}\text { Chronic care clinics } \\
\text { DS: training to physician and nurses in } \\
\text { population-based medicine and management } \\
\text { strategies (geriatric syndromes); on-the job coaching } \\
\text { of nurses by study staff. } \\
\text { DSD: }-4-4 \text { monthly visits to primary care practice for } \\
\text { development of shared treatment plan by physician } \\
\text { and nurse; session with pharmasist about } \\
\text { polypharmacy and medications associated with } \\
\text { functional decline; health status assessment. } \\
\text { SMS: } 3-4 \text { monthly visits to primary care practice for } \\
\text { self-management group session led by nurse or social } \\
\text { worker. }\end{array}$ & N.R. & 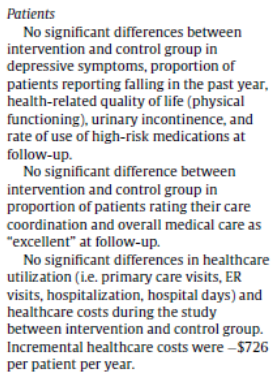 \\
\hline
\end{tabular}

\begin{tabular}{|c|c|c|c|c|c|c|c|}
\hline Author (year) & $\begin{array}{l}\text { Study design } \\
(N)^{\mathrm{a}}\end{array}$ & $\begin{array}{l}\text { Length of } \\
\text { follow-up } \\
\text { (months) }\end{array}$ & $\begin{array}{l}\text { Target } \\
\text { population }\end{array}$ & Setting & Contents of comprehensive care program ${ }^{c}$ & Usual cared $^{d}$ & Outcomese \\
\hline & & & & & & & $\begin{array}{l}\text { Professional caregivers } \\
\text { Pyysicians expressed a high level of } \\
\text { support for chronic care levels and } \\
\text { believed that they were better able to } \\
\text { meet the needs of frail older patients. }\end{array}$ \\
\hline $\begin{array}{l}\text { Counsell et al. } \\
\text { [51,52] }\end{array}$ & $\operatorname{CRCT}(N=951)$ & 24 & $\begin{array}{l}\text { Older adults } \\
\text { aged } \geq 65 \text { years } \\
\text { with an income } \\
\text { less than } 200 \% \\
\text { of the federal } \\
\text { poverty level. }\end{array}$ & $\begin{array}{l}\text { Primary care by } \\
6 \text { primary care } \\
\text { practices in the } \\
\text { USA }\end{array}$ & 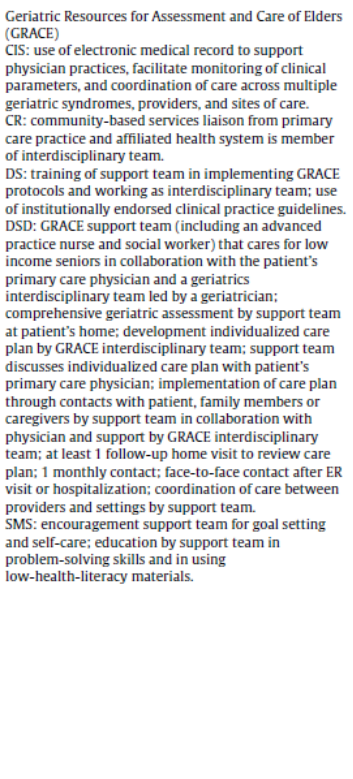 & $\begin{array}{l}\text { Access to all } \\
\text { primary and } \\
\text { specialty care } \\
\text { services available } \\
\text { (i.e. outpatient } \\
\text { geriatric } \\
\text { assessment and } \\
\text { multispecialty } \\
\text { centre, inpatient } \\
\text { acute care for } \\
\text { elders suit and } \\
\text { consult centre, } \\
\text { skilled nursing } \\
\text { facility physician } \\
\text { house calls } \\
\text { ppogram, } \\
\text { psychiatric care). }\end{array}$ & 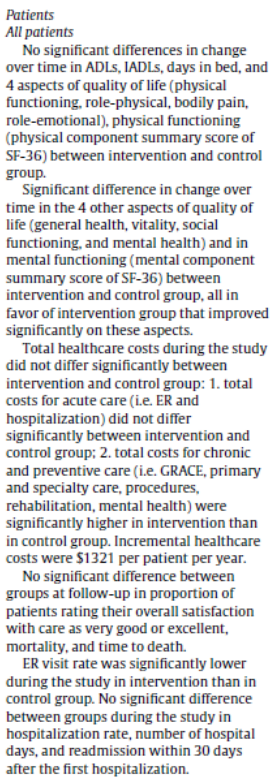 \\
\hline
\end{tabular}


Bruin, S.R. de, Versnel, N., Lemmens, L.C., Molema, C.C.M., Schellevis, F.G., Nijpels, G., Baan. C.A. Comprehensive care programs for patients with multiple chronic conditions: a systematic literature review. Health Policy: 2012, 107(2-3), 108-145

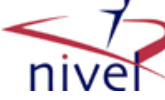

\begin{tabular}{|c|c|c|c|c|c|c|c|}
\hline $\begin{array}{l}\text { Courtney et al. } \\
{[67]}\end{array}$ & $\mathrm{RCT}(N=128)$ & 6 & $\begin{array}{l}\text { Older adults } \\
\text { aged } \geq 65 \text { years } \\
\text { with acute } \\
\text { medical } \\
\text { admission to the } \\
\text { hospital and at } \\
\text { risk for } \\
\text { readmission due } \\
\text { to multiple } \\
\text { co-morbidities, } \\
\text { impaired } \\
\text { functionality. } \\
\text { age } \geq 75 \text { years, } \\
\text { recent multiple } \\
\text { readmissions, } \\
\text { poor social } \\
\text { support or } \\
\text { history of } \\
\text { depression. }\end{array}$ & $\begin{array}{l}\text { Hospital care } \\
\text { (partly provided } \\
\text { at home) by } 1 \\
\text { tertiary hospital } \\
\text { in Australia }\end{array}$ & 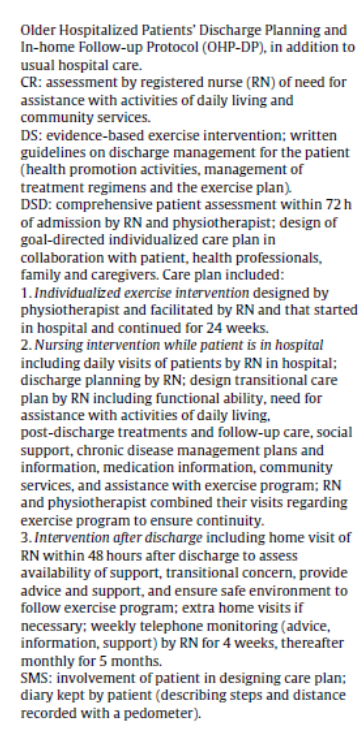 & $\begin{array}{l}\text { Usual hospital care } \\
\text { (rovutine care, } \\
\text { discharge, } \\
\text { planning. } \\
\text { rehabilitation } \\
\text { advice, in-home } \\
\text { follow up (if } \\
\text { necessary) } \\
\text { normally } \\
\text { provided). }\end{array}$ & 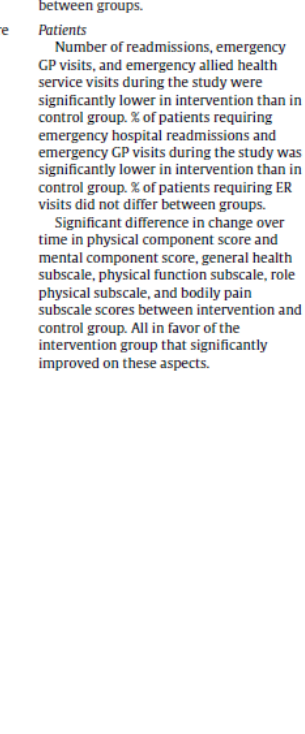 \\
\hline Author (year) & Study design $(N)^{2}$ & $\begin{array}{l}\text { Length of } \\
\text { follow-up } \\
\text { (months) }^{b}\end{array}$ & Target population & Setting & Contents of comprehensive care program ${ }^{c}$ & Usual cared & Outcomese \\
\hline $\begin{array}{l}\text { Daly et al. [72] } \\
\text { and Douglas } \\
\text { et al. [73] }\end{array}$ & $\operatorname{RCT}(N-334)$ & 2 & $\begin{array}{l}\text { ICU patients with } \\
>>27 \mathrm{~h} \mathrm{mechanical} \\
\text { ventilation }\end{array}$ & $\begin{array}{l}\text { Hospital care, } \\
\text { nursing home } \\
\text { care, and } \\
\text { rehabilitation } \\
\text { care provided by } \\
\text { long-term a acute } \\
\text { care facility. } \\
\text { nursing home, } \\
\text { and renabilitation } \\
\text { centre, } \\
\text { respectively in } \\
\text { the USA. }\end{array}$ & 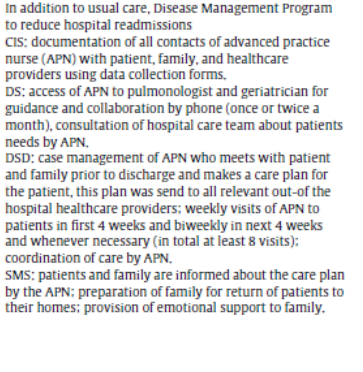 & $\begin{array}{l}\text { When patients and } \\
\text { family members } \\
\text { asked for advice } \\
\text { they were referred } \\
\text { back to their } \\
\text { primary care } \\
\text { provider, extended } \\
\text { care facility staff or } \\
\text { home care agency. }\end{array}$ & 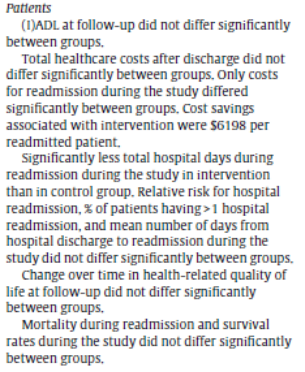 \\
\hline Dorr et al. [53,54] & $\begin{array}{l}\mathrm{ccc}(\mathrm{N}-3432 \text {, of } \\
\text { whom 1761 had } \\
\text { complex illness } \\
\text { including } \\
\text { diabetes) }\end{array}$ & 24 & $\begin{array}{l}\text { Older adults aged } \\
\geq 65 \text { years with } \\
\text { complex illness. }\end{array}$ & $\begin{array}{l}\text { Primary care by } \\
13 \text { primary care } \\
\text { clinics in the USA }\end{array}$ & 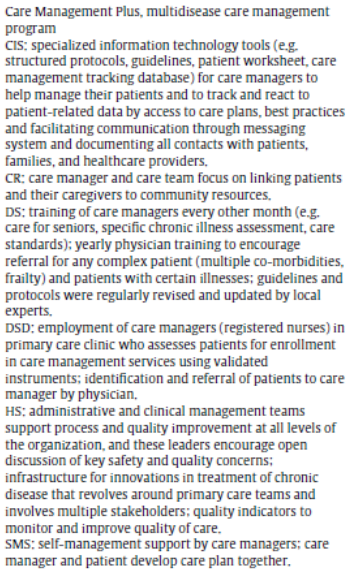 & 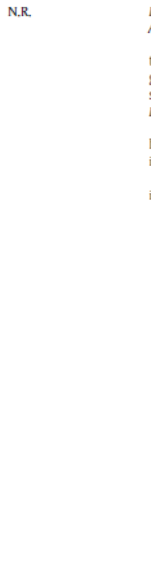 & 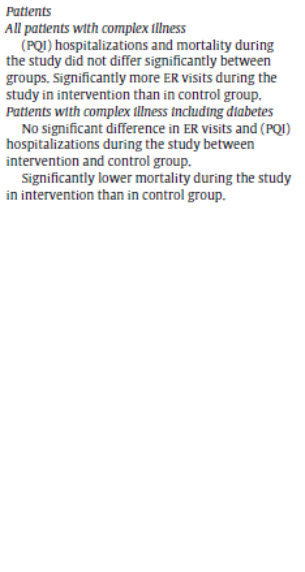 \\
\hline
\end{tabular}


Bruin, S.R. de, Versnel, N., Lemmens, L.C., Molema, C.C.M., Schellevis, F.G., Nijpels, G., Baan. C.A. Comprehensive care programs for patients with multiple chronic conditions: a systematic literature review. Health Policy: 2012, 107(2-3), 108-145

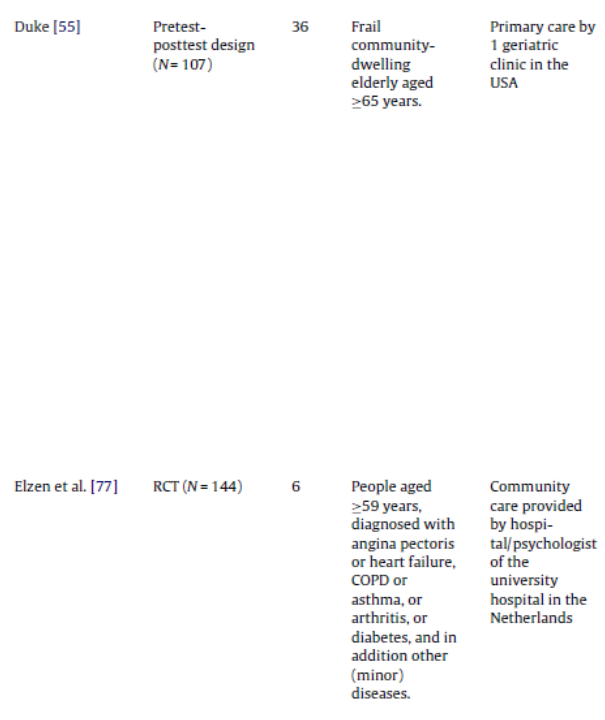

Frail Elderly Community-Based Case Management

CIS: telemedicine assessment for medically comprised patients; documentation of all relevant communicate patients' overall status and to keep physician informed.
DS: weekly patient

care conferences at geriatric fellows, support staff, pharmacy and medical
students); monthly staff education on patients

DS: collaboration between primary care physician, geriatric clinic, assisted living

manager; case management of medical and conditions, utilization of hospice and end-of-life decision making; adaptation of interventions to

gram development and evaluation

SMS: monthly education by case manager on caregivers and assisted living staff.

Chronic Disease Self-Management Program

DS: $20 \mathrm{~h}$ CDSMP-training of session leaders (pair peer leader or ly leader and health profs use of standardized leader manual during CDSMP sessions. DSD: session leaders were a trained psychologist SMS: 6-sessio participants with mixed diagnoses:
sessions focused on problem solving, appropriate exercise and medication, communication (a) included weekly action planning, modeling of behaviors, group problem solving, and individ decision-making
NA.

Changes were not tested for

ere are indications for decline in ognitive functioning and

improvement in perception of quality 54l over time.

resulting in $36 \%$ in ER visits over time, 69\% reduction in hospital

admissions and $64 \%$ reduction in

hospital length of stay over time, costs (i.e. \$580.189).
Not
specified

Patients

Health behavior (i.e. exercise, health-related quality of life, and perceived self-efficacy at follow-up did not differ significantly between groups. Intervention group was enthusiastic of 8.5 (range $0-10)$ Majority of the group enjoyed the course, indicated it as useful, and was satisfied with course materials, preparations, teaching. length of meetings, group size, and indicated the course as strenuous.

\begin{tabular}{|c|c|c|c|c|c|c|c|}
\hline Author (year) & $\begin{array}{l}\text { Study design } \\
(N)^{\mathrm{a}}\end{array}$ & $\begin{array}{l}\text { Length of } \\
\text { follow-up } \\
\text { (months }\end{array}$ & $\begin{array}{l}\text { Target } \\
\text { population }\end{array}$ & Setting & Contents of comprehensive care program ${ }^{c}$ & Usual care $^{d}$ & Outcomese $^{e}$ \\
\hline Kobb et al. [40] & $\mathrm{CCT}(\mathrm{N}=1401)$ & $\begin{array}{l}\text { Ongoing. } \\
\text { periodic data } \\
\text { collection at } 6 \\
\text { month intervals. } \\
\text { In this study } 12 \\
\text { months } \\
\text { follow-up. }\end{array}$ & $\begin{array}{l}\text { Veterans with } \\
\text { high-cost } \\
\text { medical care } \\
\text { needs } \\
\text { (>>525.000) and } \\
\text { high use (two or } \\
\text { more hospital } \\
\text { admissions, } \\
\text { frequent } \\
\text { emergency } \\
\text { room visits, and } \\
\text { unschedulded } \\
\text { walk-in visits, } \\
\text { and 10 or more } \\
\text { prescriptions) in } \\
\text { the year } \\
\text { preceding } \\
\text { enrollment. }\end{array}$ & $\begin{array}{l}\text { Home care } \\
\text { provided by } \\
\text { Veterans Health } \\
\text { Administration } \\
\text { in the USA }\end{array}$ & $\begin{array}{l}\text { Rural Home Care Project (RHCP) (see Chumbler et al. } \\
\text { [79]) }\end{array}$ & N.R. & 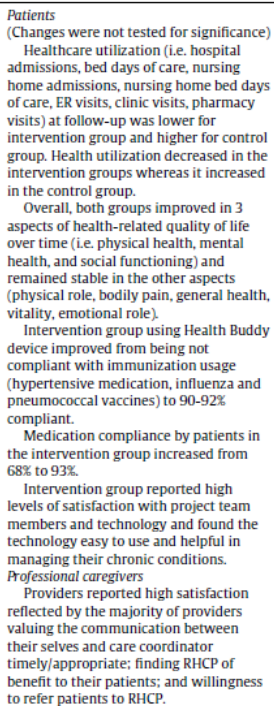 \\
\hline
\end{tabular}


Bruin, S.R. de, Versnel, N., Lemmens, L.C., Molema, C.C.M., Schellevis, F.G., Nijpels, G., Baan C.A. Comprehensive care programs for patients with multiple chronic conditions: a systematic literature review. Health Policy: 2012, 107(2-3), 108-145

\begin{tabular}{|c|c|c|c|c|c|c|c|c|c|c|c|}
\hline Krause et al., [64] & $\begin{array}{l}\text { Pretest-posttest } \\
\text { design }(N-39)\end{array}$ & 12 & \multicolumn{2}{|c|}{$\begin{array}{l}\text { Patients with } \\
\text { multiple chronic } \\
\text { conditions. }\end{array}$} & \multicolumn{2}{|c|}{$\begin{array}{l}\text { Hospital care } \\
\text { provided by } \\
\text { different } \\
\text { hospitals in the } \\
\text { usA. }\end{array}$} & \multicolumn{2}{|c|}{ 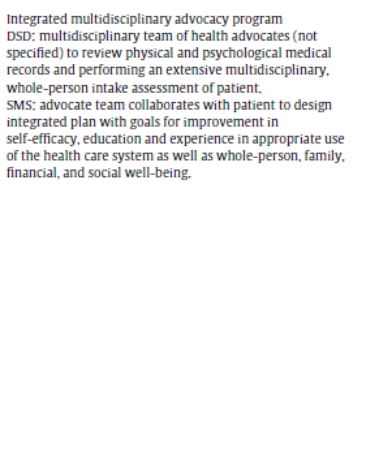 } & \multicolumn{2}{|l|}{ N.A. } & 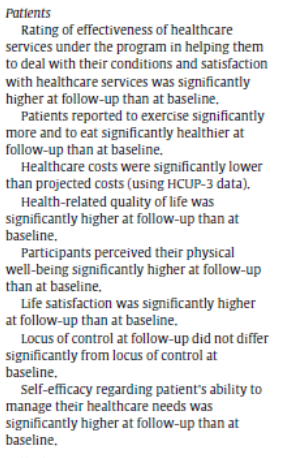 \\
\hline Leveille et al. [56] & $\operatorname{RCT}(\mathrm{N}-201)$ & 12 & \multicolumn{2}{|c|}{$\begin{array}{l}\text { Frail older people } \\
\text { aged } \geq 70 \text { years } \\
\text { with } \geq 1 \text { chronic } \\
\text { illness }\end{array}$} & \multicolumn{2}{|c|}{$\begin{array}{l}\text { Primaryl } \\
\text { community care } \\
\text { by a senior center } \\
\text { in the USA. }\end{array}$} & 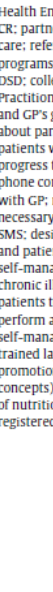 & 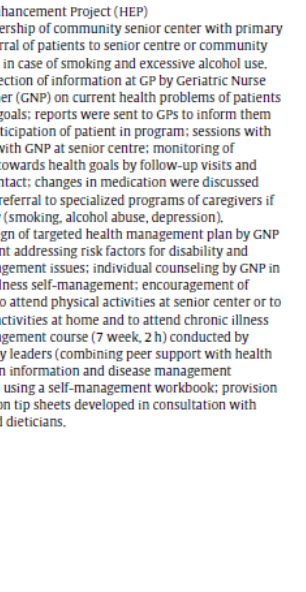 & \multicolumn{2}{|c|}{$\begin{array}{l}\text { Patients were given } \\
\text { a tour of the senior } \\
\text { center and a list of } \\
\text { scheduled activities. } \\
\text { They did not meet } \\
\text { with GNP but had } \\
\text { access to all senior } \\
\text { centre ectivities that } \\
\text { were available to } \\
\text { the intervention } \\
\text { group. }\end{array}$} & 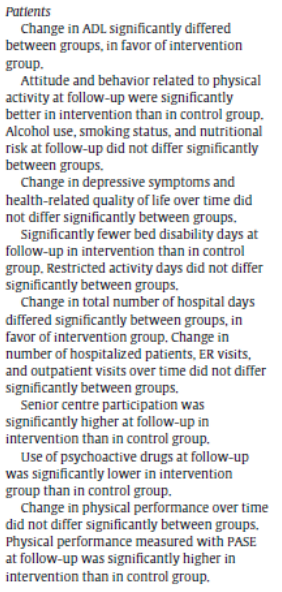 \\
\hline \multicolumn{12}{|c|}{ Table 1 (Continued ) } \\
\hline Author (year) & $\begin{array}{l}\text { Study design } \\
(N)^{\mathrm{a}}\end{array}$ & & & & & Setting & & Contents of comprehensive care program ${ }^{c}$ & & 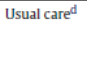 & Outcomese $^{e}$ \\
\hline Liddy et al. [41] & $\begin{array}{l}\text { Post-test only } \\
\text { study }(N=22 ; \\
\text { purposeful } \\
\text { sample of a } \\
\text { larger RCT) }\end{array}$ & & $\begin{array}{l}\text { ement } \\
\text { riable } \\
\text { ended } \\
\text { od } \\
\text { ne care } \\
\text { ere used } \\
\text { days) }\end{array}$ & $\begin{array}{l}\text { Peop } \\
\text { years } \\
\text { funct } \\
\text { declit } \\
\text { phys } \\
\text { deter }\end{array}$ & $\begin{array}{l}\text { giged } \geq 50 \\
\text { risil for } \\
\text { all } \\
\text { or } \\
\text { lation. }\end{array}$ & $\begin{array}{l}\text { Primary care } \\
1 \text { primary car } \\
\text { practice (i.e. } \\
\text { family health } \\
\text { network) in } \\
\text { Canada }\end{array}$ & $\begin{array}{l}\text { re by } \\
\text { eare } \\
\text { the } \\
\text { ne }\end{array}$ & 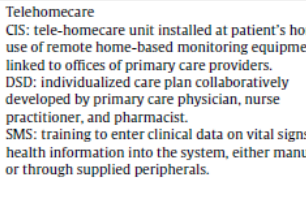 & & N.A. & $\begin{array}{l}\text { Patients } \\
\text { Patients found the technology } \\
\text { user-friendly and useful. } \\
\text { Informal caregivers } \\
\text { Informal cargervers found the } \\
\text { technology user-friendly and useful. } \\
\text { Professional caregivers } \\
\text { Healthcare providers were satisfied } \\
\text { with the technology and found } \\
\text { equipment usefult they thought it might } \\
\text { reduce number of office visits and track } \\
\text { long-term trends. }\end{array}$ \\
\hline $\begin{array}{l}\text { Littleford and } \\
\text { Kralik [57] }\end{array}$ & $\begin{array}{l}\text { Pretest-posttest } \\
\text { design (pilot } \\
\text { study) ( } N=220 \text { ) }\end{array}$ & & $\begin{array}{l}\text { e, } \\
\text { ing on } \\
\text { ion to } \\
\text { ntthe } 24 \\
\text { pilot }\end{array}$ & $\begin{array}{l}\text { Older } \\
\text { aged } \\
\text { or Ab } \\
\text { aged } \\
\text { with } \\
\text { comp } \\
\text { probl } \\
\text { risk o } \\
\text { histo } \\
\text { frequ } \\
\text { unpla } \\
\text { hosp } \\
\text { admi } \\
\text { ER vi }\end{array}$ & $\begin{array}{l}\text { ople } \\
5 \text { years } \\
\text { ginals } \\
5 \text { years } \\
\text { Itiple } \\
\text { health } \\
\text { ss and at } \\
\text { r with a } \\
\text { of } \\
t \\
\text { ted } \\
\text { ons or } \\
\text { s. }\end{array}$ & $\begin{array}{l}\text { Integrated } \\
\text { communityc } \\
\text { by a partners } \\
\text { between a } \\
\text { community } \\
\text { nursing } \\
\text { organization, } \\
\text { practice, and } \\
\text { hospital in } \\
\text { Australia }\end{array}$ & $\begin{array}{l}\text { care } \\
\text { rship } \\
\text { th, GP } \\
\text { nd }\end{array}$ & 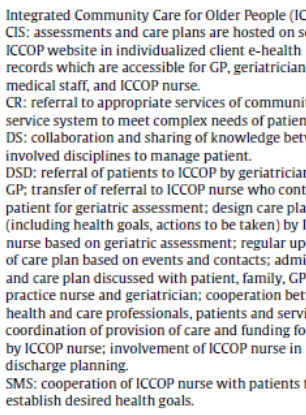 & $\begin{array}{l}\text { COP) } \\
\text { ecure } \\
\text { ED } \\
\text { ty } \\
\text { ts. } \\
\text { ween } \\
\text { hor } \\
\text { acts } \\
\text { nt } \\
\text { ccop } \\
\text { date } \\
\text { ssion } \\
\text { ween } \\
\text { ices: } \\
\text { rcare } \\
\\
\end{array}$ & N.A. & $\begin{array}{l}\text { Patients } \\
\text { ER visits reduced with } 51 \% \text { during the } \\
\text { sttudy compared with the number of visits } \\
\text { before enrollment Hospital length of stay } \\
\text { refucuced with } 37 \% \text { during the study } \\
\text { compared with the total number of } \\
\text { hospital days before enrollment. }\end{array}$ \\
\hline
\end{tabular}


Bruin, S.R. de, Versnel, N., Lemmens, L.C., Molema, C.C.M., Schellevis, F.G., Nijpels, G., Baan, C.A. Comprehensive care programs for patients with multiple chronic conditions: a systematic literature review. Health Policy: 2012, 107(2-3), 108-145

\begin{tabular}{|c|c|c|c|c|c|c|c|}
\hline $\begin{array}{c}\text { Markle-Reid } \\
\text { et al. [58] }\end{array}$ & $\operatorname{RCT}(N=288)$ & 6 & $\begin{array}{l}\text { Frail older } \\
\text { people aged } \geq 75 \\
\text { years eligible for } \\
\text { home care } \\
\text { services. }\end{array}$ & $\begin{array}{l}\text { Home care by } \\
\text { home care } \\
\text { organization in } \\
\text { Canada }\end{array}$ & $\begin{array}{l}\text { In addition to usual home care, proactive nursing } \\
\text { health promotion intervention } \\
\text { CR: referral to and coordination of community } \\
\text { services. } \\
\text { DSD: health assessment to support personal } \\
\text { resources; identifying and managing risk factors for } \\
\text { functional decline; regular home visits or telephone } \\
\text { contacts by registsered nurse from a } \\
\text { community-nursing agency; providing caregiver } \\
\text { support. } \\
\text { SMS: health education by registered nurse about } \\
\text { management of illness and healthy lifestyles using } \\
\text { empowerment strategies. }\end{array}$ & $\begin{array}{l}\text { Usual home care } \\
\text { services consisting } \\
\text { of case } \\
\text { management, } \\
\text { personal care, } \\
\text { home support } \\
\text { (home making). } \\
\text { nursing. } \\
\text { occupational } \\
\text { therapy. } \\
\text { physiotherapy, } \\
\text { social work, and } \\
\text { speech language } \\
\text { therapy through } \\
\text { community-based } \\
\text { agencies. }\end{array}$ & 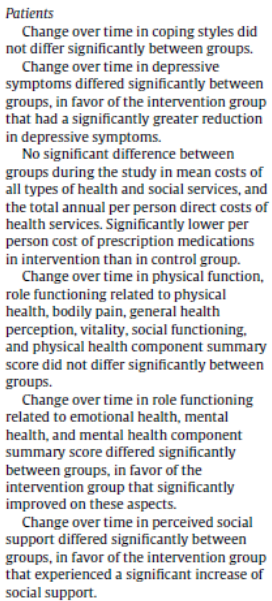 \\
\hline $\begin{array}{l}\text { Marsteller et al. } \\
\text { [59] }\end{array}$ & $\operatorname{CRCT}(N=49)$ & 12 & $\begin{array}{l}\text { Primary care } \\
\text { physicians } \\
\text { providing care } \\
\text { to multimorbid } \\
\text { people aged } \geq 65 \\
\text { years and at } \\
\text { high risk for } \\
\text { incurring high } \\
\text { healthcare costs } \\
\text { in the coming } \\
\text { year. }\end{array}$ & $\begin{array}{l}\text { Primary care by } \\
8 \text { primary care } \\
\text { practices in the } \\
\text { USA }\end{array}$ & Guided Care (see Boult et al. [45]) & Not specified & 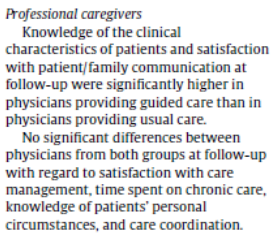 \\
\hline
\end{tabular}

\begin{tabular}{|c|c|c|c|c|c|c|c|}
\hline Author (year) & $\begin{array}{l}\text { Study design } \\
(N)^{\mathrm{a}}\end{array}$ & $\begin{array}{l}\text { Length of } \\
\text { follow-up } \\
\text { (months) }^{b}\end{array}$ & $\begin{array}{l}\text { Target } \\
\text { population }\end{array}$ & Setting & Contents of comprehensive care program ${ }^{c}$ & Usual care $^{d}$ & Outcomese $^{e}$ \\
\hline Mitton et al. [60] & $\begin{array}{l}\text { Pretest-posttest } \\
\text { design }(N=37)\end{array}$ & 12 & $\begin{array}{l}\text { Older patients } \\
\text { with high } \\
\text { healthcare } \\
\text { needs and } \\
\text { chronic or } \\
\text { complex } \\
\text { medical } \\
\text { problems. }\end{array}$ & $\begin{array}{l}\text { Primary care by } \\
\text { collaborative } \\
\text { partrership } \\
\text { between home } \\
\text { care } \\
\text { organization } \\
\text { and primary } \\
\text { care practice in } \\
\text { Canada. }\end{array}$ & $\begin{array}{l}\text { Nurse Physician Collaborative Partnership } \\
\text { cIS: electronic patient health record system in which } \\
\text { nurses could access patients' records and } \\
\text { communicate with physicians by e-mail. } \\
\text { CR: linkage to community supports (no further details } \\
\text { available). } \\
\text { DS: shared care guidelines; professional courses for } \\
\text { project nurses with knowledge and skill gaps; } \\
\text { consultation with partners and other healthcare } \\
\text { providers (e.g. pharmacist); discussion between nurse } \\
\text { and physician at monthly care planning meeting. } \\
\text { DSD: collaborative partnership between home care } \\
\text { nurses and family physicians, services included } \\
\text { referral and admissions, development, and } \\
\text { modification of fhared care plan for each patient: } \\
\text { comprehensive biopsychological arsesssment; active } \\
\text { patient management; standard and advanced nursing } \\
\text { interventions. } \\
\text { SMS: health education and self management. }\end{array}$ & N.A. & 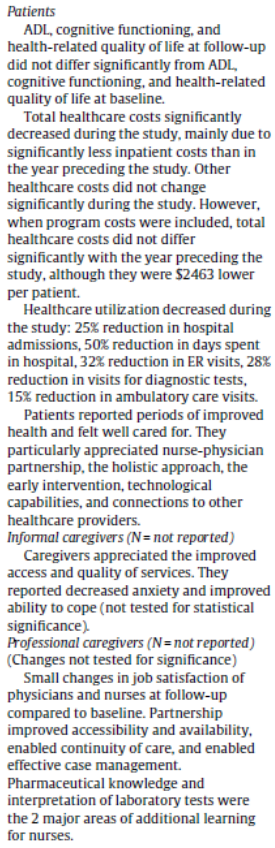 \\
\hline
\end{tabular}


Bruin, S.R. de, Versnel, N., Lemmens, L.C., Molema, C.C.M., Schellevis, F.G., Nijpels, G., Baan C.A. Comprehensive care programs for patients with multiple chronic conditions: a systematic literature review. Health Policy: 2012, 107(2-3), 108-145

\begin{tabular}{|c|c|c|c|c|c|c|c|}
\hline Naylor et al. [74] & $\mathrm{RCT}(N=239)$ & $\begin{array}{l}\mathrm{Pa} \\
\text { or } \\
\text { ho } \\
\text { wi } \\
\text { fai }\end{array}$ & $\begin{array}{l}\text { Patients aged } 65 \\
\text { or older and } \\
\text { hospitalized } \\
\text { with heart } \\
\text { failure. }\end{array}$ & $\begin{array}{l}\text { Hospital care by } \\
6 \text { hospitals in } \\
\text { the USA }\end{array}$ & 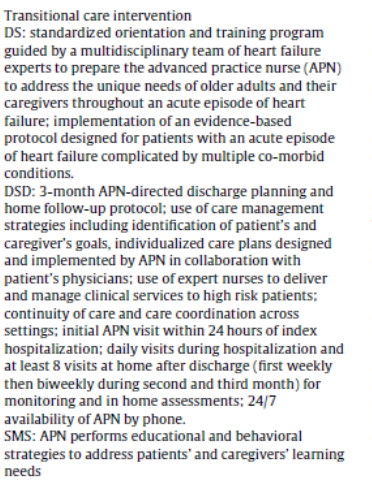 & $\begin{array}{l}\text { Routine care } \\
\text { provided by the } \\
\text { admitting hospital, } \\
\text { including } \\
\text { site-specific heart } \\
\text { failure patient } \\
\text { management and } \\
\text { dischargen planning } \\
\text { critical paths, and } \\
\text { if referred, } \\
\text { standard home } \\
\text { care agency care. } \\
\text { The discharge } \\
\text { planning was } \\
\text { similar in all } \\
\text { hospitals, also } \\
\text { home care was } \\
\text { similar. Home care } \\
\text { included use of } \\
\text { liaison nurses, } \\
\text { availability of } \\
\text { skilled home care } \\
\text { services, and nurse } \\
\text { 24 a day hours on } \\
\text { call. }\end{array}$ & 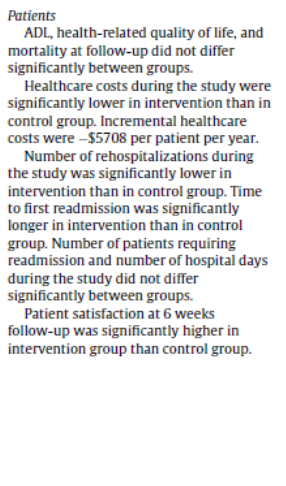 \\
\hline $\begin{array}{l}\text { Procter and } \\
\text { Single [42] }\end{array}$ & $\begin{array}{l}\text { Pretest-posttest } \\
\text { design }(N=25)\end{array}$ & $\begin{array}{l}\text { Ol } \\
\text { ag } \\
\text { did } \\
\text { he } \\
\text { CO } \\
\text { sta } \\
\text { (co } \\
\text { wi } \\
\text { ch } \\
\text { co } \\
\text { all } \\
\text { at } \\
\text { ex } \\
\text { rey } \\
\text { ho } \\
\text { ad }\end{array}$ & $\begin{array}{l}\text { Older people } \\
\text { aged } \geq 65 \text { years, } \\
\text { diagnosed with } \\
\text { heart failure or } \\
\text { CopD and early } \\
\text { stage dementia } \\
\text { (combinations } \\
\text { with other } \\
\text { chronic } \\
\text { conditions were } \\
\text { allowed), living } \\
\text { at home, and } \\
\text { experiencing } \\
\text { repeated } \\
\text { hospital } \\
\text { admissions. }\end{array}$ & $\begin{array}{l}\text { Primary care in } \\
\text { the UK, setting } \\
\text { unknown. }\end{array}$ & 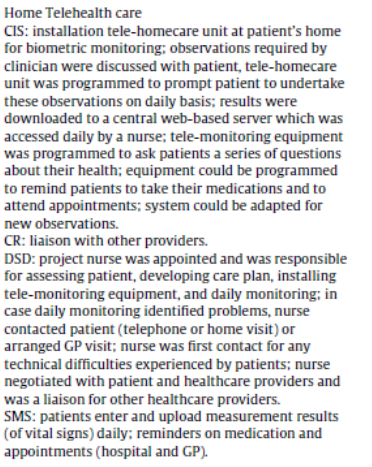 & N.A. & $\begin{array}{l}\text { Patients } \\
\text { (Changes were not tested for significance) } \\
\text { Patients reported increased confidence } \\
\text { in mananging diseases a f follow-up. } \\
\text { Number of hospitalizations decreased } \\
\text { with } 38 \text { \% during the study. } \\
\text { Informal caregivers } \\
\text { Informal caregivers reported increased } \\
\text { confidence in managing diseases at } \\
\text { follow-up. } \\
\text { Professional caregivers } \\
\text { In } 14 \text { out of of } 25 \text { patients early detection } \\
\text { and treatment of problems occurred } \\
\text { during the study. }\end{array}$ \\
\hline \multicolumn{8}{|l|}{ Table 1 (Continued) } \\
\hline Author (year) & $\begin{array}{l}\text { Study design } \\
(N)^{\mathrm{a}}\end{array}$ & $\begin{array}{l}\begin{array}{l}\text { Length of } \\
\text { follow-up } \\
\text { (months })^{b}\end{array} \\
\end{array}$ & $\begin{array}{l}\text { Taryet } \\
\text { population }\end{array}$ & Setting & Contents of comprehensive care program ${ }^{c}$ & Usual care $^{\mathrm{d}}$ & Outcomese $^{e}$ \\
\hline Rose et al. [78] & $\begin{array}{l}\text { Pretest-posttest } \\
\text { design }(N=175)\end{array}$ & 6 & $\begin{array}{l}\text { Low income } \\
\text { older urban } \\
\text { African } \\
\text { American adults } \\
\text { with } \geq 1 \text { chronic } \\
\text { condition. }\end{array}$ & $\begin{array}{l}\text { Community care } \\
\text { provided by } \\
\text { community sites } \\
\text { (i.e. esior } \\
\text { citizen centers, } \\
\text { senior housing } \\
\text { for low income } \\
\text { older people, } \\
\text { churches) in the } \\
\text { USA }\end{array}$ & $\begin{array}{l}\text { Chronic Disease Self-Management Program (CDSMP) } \\
\text { (see Elzen en al. [77] } \\
\text { DSD: in additition to session leaders reported by Elzen } \\
\text { et al [177] co-leaders were lay African American older } \\
\text { adults, who were part of the community. } \\
\text { SMS: workshops consisted of 10-20 participants } \\
\text { instead of } 10-13 \text { participants as reported by Elzen } \\
\text { et al. [77]. }\end{array}$ & N.A. & 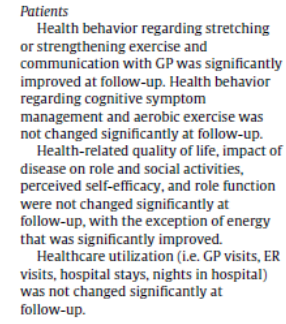 \\
\hline $\begin{array}{l}\text { Rubenstein et al. } \\
\text { [61] }\end{array}$ & $\operatorname{RCT}(N=792)$ & 36 & $\begin{array}{l}\text { Community- } \\
\text { dwelling } \\
\text { veterans aged } \\
\geq 65 \text { years with } \\
\text { at least } 1 \text { clinic } \\
\text { visit in the last } \\
18 \text { months. }\end{array}$ & $\begin{array}{l}\text { Primary care } \\
\text { provided by } \\
\text { Department of } \\
\text { Veterans affairs } \\
\text { ambulatory care } \\
\text { centre in the } \\
\text { USA. }\end{array}$ & 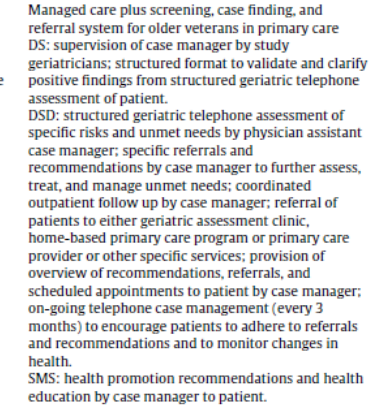 & $\begin{array}{l}\text { Managed care } \\
\text { without screening. } \\
\text { case finding and } \\
\text { referral system. }\end{array}$ & $\begin{array}{l}\text { Patients } \\
\text { Change over time in (I)ADL, depressive } \\
\text { symptoms, fall incidence, health-related } \\
\text { quality of life, and urinary incontinence } \\
\text { did not differ significantly between } \\
\text { groups. } \\
\text { Healthcare utilization (i.e. number of } \\
\text { hospital days, number of patients } \\
\text { admitted to hospital) during the study did } \\
\text { not differ significantly between groups. }\end{array}$ \\
\hline
\end{tabular}


Bruin, S.R. de, Versnel, N., Lemmens, L.C., Molema, C.C.M., Schellevis, F.G., Nijpels, G., Baan C.A. Comprehensive care programs for patients with multiple chronic conditions: a systematic literature review. Health Policy: 2012, 107(2-3), 108-145

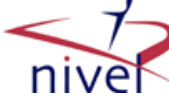

\begin{tabular}{|c|c|c|c|c|c|c|c|c|c|}
\hline $\begin{array}{l}\text { Saltvedt et al. } \\
\text { [68,69] }\end{array}$ & $\mathrm{RCT}(\mathrm{N}=254)$ & 12 & & $\begin{array}{l}\text { Acutely sick, } \\
\text { frail older } \\
\text { pationts aged } \\
\geq 75 \text { years wh } \\
\text { wereacutely } \\
\text { admitted } \\
\text { hospital. }\end{array}$ & & $\begin{array}{l}\text { Hospital care by } \\
1 \text { hospital in } \\
\text { Norway. }\end{array}$ & $\begin{array}{l}\text { Geriatric Evaluation Management Unit (GEMU) } \\
\text { DS: Meetings of all disciplines (twice a week) to } \\
\text { report assessments, discuss problems, set gaols, and } \\
\text { plan discharge. Primary health care nurses were } \\
\text { telephonend to discuss arrangements of fischarge, } \\
\text { when considered aspropriate by the staff } \\
\text { DSD: interdisciplinary approach with close } \\
\text { collaboration between all disciplines; design } \\
\text { individual rehabilitation plans for each patient. }\end{array}$ & $\begin{array}{l}\text { Usual treatment of } \\
\text { Department of } \\
\text { Internal Medicine }\end{array}$ & 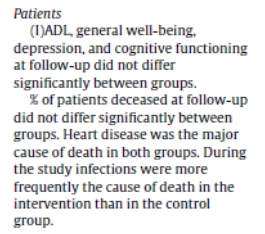 \\
\hline $\begin{array}{l}\text { Schmader et al. } \\
{[70]}\end{array}$ & $\mathrm{RCT}(N=864)$ & $\begin{array}{l}\text { Inpatient } \\
\text { period: variat } \\
\text { Outpatient } \\
\text { period: } 12 \\
\text { month minu } \\
\text { inpatient peri }\end{array}$ & $\begin{array}{l}\text { iable } \\
\text { nus } \\
\text { eriod. }\end{array}$ & $\begin{array}{l}\text { Hospitalized } \\
\text { frail veterans } \\
\text { aged } \geq 65 \text { yea } \\
\text { admitted to a } \\
\text { medical or } \\
\text { surgical warc } \\
\text { for } \geq 3 \text { days. }\end{array}$ & & $\begin{array}{l}\text { Hospital care by } \\
11 \text { Veterans } \\
\text { Affairs medical } \\
\text { centers in the } \\
\text { USA. }\end{array}$ & 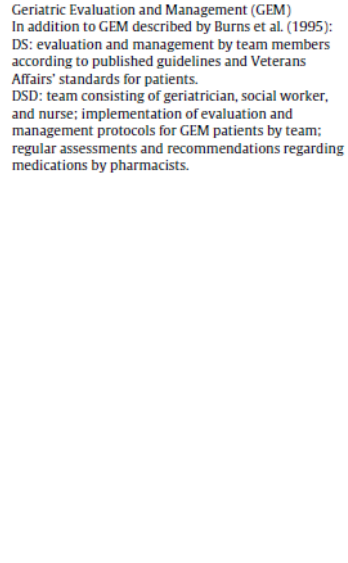 & $\begin{array}{l}\text { Usual inpatient } \\
\text { care: customary } \\
\text { medical or surgical } \\
\text { treatament by } \\
\text { physicians (or } \\
\text { others nuder their } \\
\text { direction). } \\
\text { Uusual outpatient } \\
\text { care: customary } \\
\text { care delivered by } \\
\text { ambulatory care } \\
\text { physicians (or } \\
\text { others under their } \\
\text { direction). }\end{array}$ & 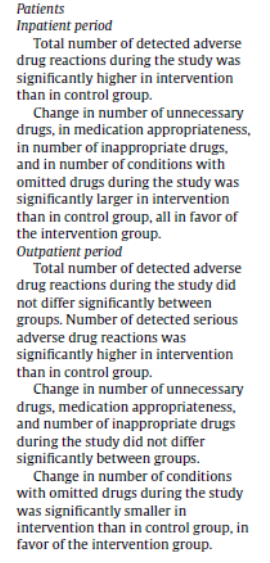 \\
\hline \multicolumn{10}{|l|}{ Table 1 (Continued) } \\
\hline Author (year) & Study design $(N)^{2}$ & $\begin{array}{l}\text { Length of } \\
\text { follow-up } \\
(\text { months })^{b}\end{array}$ & Target & t population & Setting & & ents of comprehensive care program ${ }^{c}$ & ual cares & tcomest $^{2}$ \\
\hline $\begin{array}{l}\text { Sorrento et al. } \\
\text { [ } 62]\end{array}$ & $\begin{array}{l}\begin{array}{l}\text { Pretest-posttest } \\
\text { design }(N-273)\end{array}\end{array}$ & 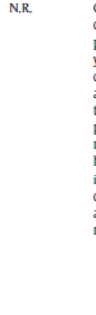 & $\begin{array}{l}\text { Comm } \\
\text { dwellit } \\
\text { people } \\
\text { years } \\
\text { chroni } \\
\text { and wi } \\
\text { the fol } \\
\text { proble } \\
\text { memo } \\
\text { history } \\
\text { incont } \\
\text { depres } \\
\text { anxiet } \\
\text { malnu }\end{array}$ & $\begin{array}{l}\text { nunity- } \\
\text { ing older } \\
\text { e aged } \geq 75 \\
\text { with } \geq 2 \\
\text { ic illlesses } \\
\text { vith } \geq 1 \text { of } \\
\text { llowing } \\
\text { ens: } \\
\text { pry defficits, } \\
\text { y of falls, } \\
\text { tinence, } \\
\text { ssion, } \\
\text { ty, and } / \text { or } \\
\text { trition. }\end{array}$ & & $\begin{array}{l}\text { Ger } \\
\text { DS: } \\
\text { and } \\
\text { use } \\
\text { pat } \\
\text { DSt } \\
\text { inte } \\
\text { wor } \\
\text { wat } \\
\text { acc } \\
\text { con } \\
\text { at-r } \\
\text { app } \\
\text { asse } \\
\text { wri } \\
\text { dec } \\
\text { SM } \\
\text { to it }\end{array}$ & 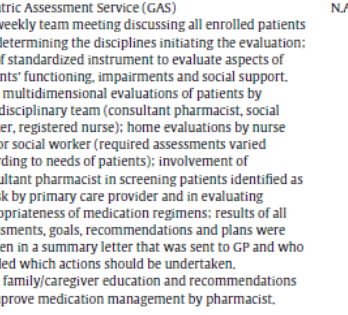 & & 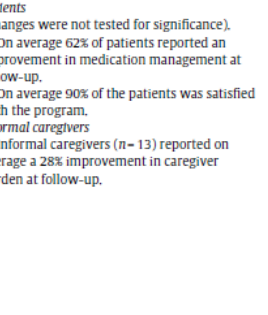 \\
\hline Taylor et al. [76] & $\operatorname{RCT}(\mathrm{N}-169)$ & 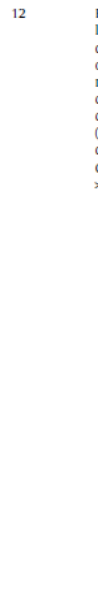 & $\begin{array}{l}\text { Patient } \\
\text { longste } \\
\text { diabet: } \\
\text { or mor } \\
\text { medice } \\
\text { co-mo } \\
\text { condit } \\
\text { (hyper } \\
\text { dyslipi } \\
\text { c cD) a } \\
>10 \%\end{array}$ & $\begin{array}{l}\text { ts with } \\
\text { tanding } \\
\text { tes with one } \\
\text { re major } \\
\text { cal } \\
\text { rtbid } \\
\text { tions } \\
\text { rtension, } \\
\text { idemia or } \\
\text { and HbAlc }\end{array}$ & $\begin{array}{l}\text { Primar } \\
\text { provid } \\
\text { manag } \\
\text { organiz } \\
\text { the US. }\end{array}$ & $\begin{array}{l}\text { Nur } \\
\text { DS: } \\
\text { use } \\
\text { nur } \\
\text { hyp } \\
\text { DSt } \\
\text { asse } \\
\text { foll } \\
\text { phy } \\
\text { tor } \\
\text { SM: } \\
\text { clas } \\
\text { diss } \\
\text { tele } \\
\text { me }\end{array}$ & 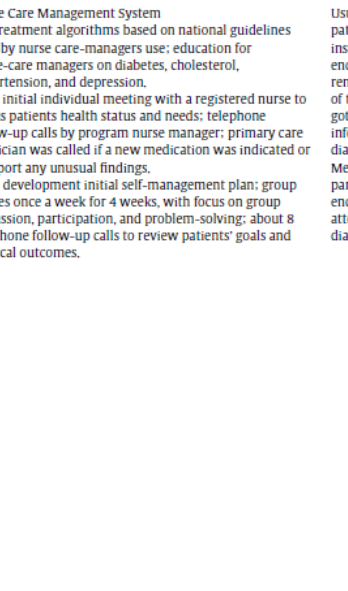 & $\begin{array}{l}\text { Jal medical care, } \\
\text { jents were } \\
\text { tructed and } \\
\text { cuoragged to } \\
\text { nain under care } \\
\text { their physicaian, } \\
\text { a folder with } \\
\text { ormation on } \\
\text { betes and a } \\
\text { dical Alert } \\
\text { mphlet, and were } \\
\text { couraged to } \\
\text { end general } \\
\text { betes education. }\end{array}$ & 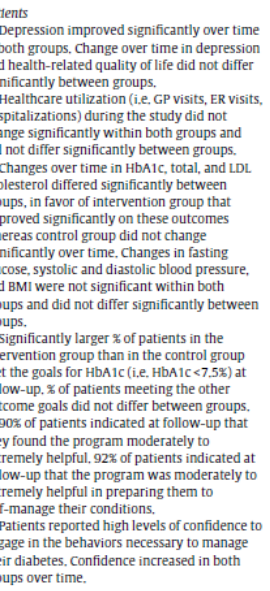 \\
\hline
\end{tabular}


Bruin, S.R. de, Versnel, N., Lemmens, L.C., Molema, C.C.M., Schellevis, F.G., Nijpels, G., Baan C.A. Comprehensive care programs for patients with multiple chronic conditions: a systematic literature review. Health Policy: 2012, 107(2-3), 108-145

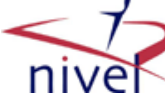

\begin{tabular}{|c|c|c|c|c|c|c|}
\hline Tibaldi et al. [71] & $\mathrm{RCT}(\mathrm{N}=109)$ & $\begin{array}{l}\text { Variable } \\
\text { (depending } \\
\text { on time to } \\
\text { discharge) }\end{array}$ & $\begin{array}{l}\text { Frail older } \\
\text { patients with } \\
\text { dementia } \\
\text { requiring } \\
\text { admission to a } \\
\text { hospital } \\
\text { emergency } \\
\text { department for } \\
\text { acute illness. }\end{array}$ & $\begin{array}{l}\text { Hospital care } \\
\text { (provided at } \\
\text { home by } 1 \\
\text { hospital in Italy }\end{array}$ & $\begin{array}{l}\text { Geriatric Home Hospitalization Service (GHHS) } \\
\text { DSD: GHSH team ( } 5 \text { geriatricians, } 14 \text { nurses, } 4 \\
\text { physiotherapists, } 1 \text { dieticician, } 1 \text { social worker, } 1 \\
\text { counselor) providing physician and nursing care, } \\
\text { medicines, and appropriated diagnostic and therapeutic } \\
\text { interventions at home; service operates } 12 \mathrm{~h} \text { a day } 7 \\
\text { days a week: GHHS doctors and nurses are available } \\
\text { for patients at all times. } \\
\text { SMS: caregivers are informed about the emergency } \\
\text { plan and encouraged to telephone if problems or } \\
\text { questions arise. }\end{array}$ & $\begin{array}{l}\text { Admission to } \\
\text { general medical } \\
\text { ward. }\end{array}$ \\
\hline $\begin{array}{l}\text { Wright et al. } \\
\text { [11] }\end{array}$ & $\begin{array}{l}\text { Post-test only } \\
\text { study (without } \\
\text { control) (pillot) } \\
(N=118)\end{array}$ & $\begin{array}{l}\text { Time of } \\
\text { measure- } \\
\text { ment was } \\
12 \text { months } \\
\text { after start } \\
\text { of AD-UFE }\end{array}$ & $\begin{array}{l}\text { Low-income } \\
\text { older patients } \\
\text { with chronic } \\
\text { conditions and } \\
\text { functional } \\
\text { impairment at } \\
\text { high risk for re- } \\
\text { hospitalization } \\
\text { or nursing home } \\
\text { placement. }\end{array}$ & $\begin{array}{l}\text { Primary care by } \\
\text { non-profit } \\
\text { healthcare } \\
\text { delivery } \\
\text { network in the } \\
\text { USA. }\end{array}$ & 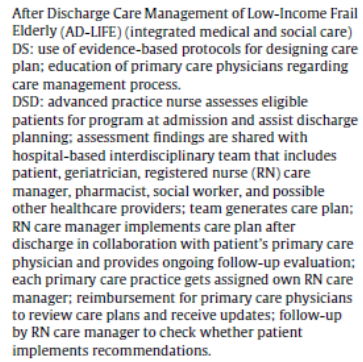 & N.A. \\
\hline
\end{tabular}

rofessional caregivers $(\mathrm{N}=13)$ 69\% of caregivers indicated that they
strongly recommended adoption of the program by their healthcare system, that spent with patients 319 dindicaseded tim they felt that the program increased the time spent with patients.

Patients
Significantly lower $\%$ of patients with behavioral disturbances (L.e. sleeping and using antipsychotic drugs at discharge in intervention than in control group. No significant difference in mortality
during the study between irooups Informal caregivers

Change in caregiver stress over time was significantly larger in intervention intervention group where caregiver stres reduced significantly.

Patients
Number of hospital admissions per
1000 patients decreased resulting in decreased healthcare costs of $\$ 12260$ per patient per year during the study (not tested for significance).

follow-up that he progindicated at their health, had made it easier to get healthcare services, had them provide with a better understanding of therr
disease and had not subjective decline in health during the
year. $93 \%$ of patients rated their experience as "good" or "excellent" and program to their friends. Professional caregivers Physicians indicated to be highly
shisfod an follow-up

\begin{tabular}{|c|c|c|c|c|c|c|c|}
\hline Author (year) & $\begin{array}{l}\text { Study design } \\
(N)^{\mathrm{a}}\end{array}$ & $\begin{array}{l}\text { Length of } \\
\text { follow-up } \\
\text { (months) }^{b}\end{array}$ & $\begin{array}{l}\text { Target } \\
\text { population }\end{array}$ & Setting & Contents of comprehensive care program ${ }^{c}$ & Usual care $^{d}$ & Outcomese $^{e}$ \\
\hline Zhang et al. [75] & $\operatorname{CCT}(N=65132)$ & 24 & $\begin{array}{l}\text { Medicaid } \\
\text { patients having } \\
\text { one of five of the } \\
\text { following } \\
\text { diseases: } \\
\text { diabetes, } \\
\text { hyperten- } \\
\text { sion/congestive } \\
\text { heart failure, } \\
\text { depression, } \\
\text { gastro- } \\
\text { esophagal reflux } \\
\text { disease/peptic } \\
\text { ulcer disease } \\
\text { and } \\
\text { Asthma//CoPD } \\
\text { and/or } \\
\text { co-morbiditities. }\end{array}$ & $\begin{array}{l}\text { Primary and//or } \\
\text { pharmaceutical } \\
\text { care by primary } \\
\text { care practices } \\
\text { and/or } \\
\text { pharmacies in } \\
\text { the USA }\end{array}$ & $\begin{array}{l}\text { Disease State Management (DSM) program } \\
\mathrm{I}_{1} \text { : physicians intervened } \\
\mathrm{L}_{2} \text { : both physicians and pharmacists intervened } \\
\text { CIS: Mailing with claims-data based routine feedback } \\
\text { sheet and clinical summary with latest results on } \\
\text { outcome measures. } \\
\text { DS: Mailing of eductional materials on the five } \\
\text { diseases and their co-morbiditities on quarterly basis } \\
\text { for } 3 \text { years to participating physicians and } \\
\text { pharmacists. } \\
\text { SMS: physicians and pharmacists were asked to } \\
\text { consult with their patients and/or patient } \\
\text { representatitives about their life styles, treatment, and } \\
\text { drug use. }\end{array}$ & $\begin{array}{l}\text { No } \\
\text { interventions }\end{array}$ & 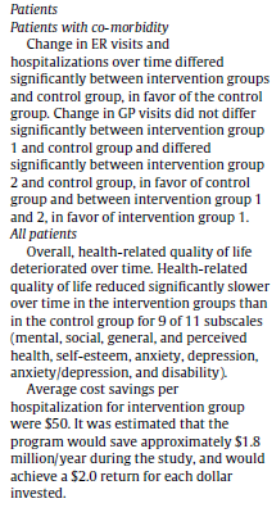 \\
\hline
\end{tabular}


Bruin, S.R. de, Versnel, N., Lemmens, L.C., Molema, C.C.M., Schellevis, F.G., Nijpels, G., Baan, C.A. Comprehensive care programs for patients with multiple chronic conditions: a systematic literature review. Health Policy: 2012, 107(2-3), 108-145

Table 2

Results of methodological quality assessment of included studies.

\begin{tabular}{|c|c|c|c|c|c|c|c|}
\hline Study & Randomization ${ }^{2}$ & $\begin{array}{l}\text { Similar at } \\
\text { baseline }^{\mathrm{b}}\end{array}$ & Compliance $e^{r}$ & $\begin{array}{l}\text { Drop-out } \\
\text { rate }^{d}\end{array}$ & ITT-analysis ${ }^{e}$ & $\begin{array}{l}\text { Adjustments for } \\
\text { confounding variables } \\
\text { in analysist }\end{array}$ & $\begin{array}{l}\text { Total } \\
\text { score }\end{array}$ \\
\hline Anonymous [63] & N.A. & N.A. & $?$ & NA. & NA. & NA. & 0 \\
\hline Béland et al. [43] & + & + & ? & + & + & + & 5 \\
\hline $\begin{array}{l}\text { Boult et al., Boyd et al., } \\
\text { Leff et al., and Wolff } \\
\text { et al. [44-47] }\end{array}$ & + & - & $?$ & + & + & + & 4 \\
\hline $\begin{array}{l}\text { Boyd et al. and Sylvia } \\
\text { et al. }[48,49]\end{array}$ & N.A. & - & $?$ & + & + & ? & 2 \\
\hline Brand et al. [65] & N.A. & - & ? & + & NA. & + & 2 \\
\hline Burns et al. [66] & + & + & ? & ? & - & NA. & 2 \\
\hline Chumbler et al. [79] & N.A. & - & $?$ & + & NA. & + & 2 \\
\hline Coleman et al. [50] & $?$ & + & $?$ & + & + & + & 4 \\
\hline Counsell et al. [51,52] & + & + & $?$ & + & + & NA. & 4 \\
\hline Courtney et al. [67] & + & + & ? & + & + & NA. & 4 \\
\hline $\begin{array}{l}\text { Daly et al. and Douglas } \\
\text { et al. }[72,73]\end{array}$ & + & + & ? & ? & - & NA. & 2 \\
\hline Dorr et al. [53,54] & N.A. & + & ? & + & NA. & NA. & 2 \\
\hline Duke et al. [55] & N.A. & N.A. & ? & + & NA. & NA. & 1 \\
\hline Elzen et al. [77] & + & + & ? & + & - & NA. & 3 \\
\hline Kobb et al. [40] & N.A. & $?$ & + & + & NA. & $?$ & 2 \\
\hline Krause et al. [64] & N.A. & N.A. & ? & + & NA. & NA. & 1 \\
\hline Leveille et al. [56] & + & - & ? & + & + & + & 4 \\
\hline Liddy et al. [41] & N.A. & N.A. & + & NA. & NA. & NA. & 1 \\
\hline Littleford and Kralik [57] & N.A. & N.A. & ? & + & NA. & NA. & 1 \\
\hline Markle - Reid et al. [58] & + & + & $?$ & + & + & NA. & 4 \\
\hline Marsteller et al. [59] & $?$ & + & ? & + & - & $?$ & 2 \\
\hline Mitton et al. [60] & N.A. & N.A. & ? & + & NA. & NA. & 1 \\
\hline Naylor et al. [74] & + & + & ? & + & + & NA. & 4 \\
\hline Procter and Single [42] & N.A. & N.A. & - & ? & NA. & NA. & 0 \\
\hline Rose et al. [78] & N.A. & N.A. & ? & - & NA. & NA. & 0 \\
\hline Rubenstein et al. [61] & $?$ & + & ? & + & + & $?$ & 3 \\
\hline Saltvedt et al. $[68,69]$ & + & + & ? & + & - & NA. & 3 \\
\hline Schmader et al. [70] & + & + & ? & ? & - & NA. & 2 \\
\hline Sorrento et al. [62] & N.A. & N.A. & ? & $?$ & NA. & NA. & 0 \\
\hline Taylor et al. [76] & $?$ & + & $?$ & + & - & NA. & 2 \\
\hline Tibaldi et al.[71] & $?$ & $?$ & ? & $?$ & + & $?$ & 1 \\
\hline Wright et al. [11] & N.A. & N.A. & $?$ & NA. & NA. & NA. & 0 \\
\hline Zhang et al. [75] & N.A. & $?$ & ? & $?$ & NA. & NA. & 0 \\
\hline
\end{tabular}

N.A.- not applicable; +- criterion fulfilled; -- criterion not fulfilled; ?-lack of information.

2. Was the method of randomization adequate?

b Were the groups similar at baseline regarding the most important prognostic indicators?

c Was the compliance of patients acceptable in all groups?

Was the drop-out rate described and acceptable?

e Did the analysis include an intention-to-treat analysis.

${ }^{r}$ Are adjustments made for confounding variables and/or differences in prognostic indicators at baseline? 
Bruin, S.R. de, Versnel, N., Lemmens, L.C., Molema, C.C.M., Schellevis, F.G., Nijpels, G., Baan C.A. Comprehensive care programs for patients with multiple chronic conditions: a systematic literature review. Health Policy: 2012, 107(2-3), 108-145

Table 3a

\begin{tabular}{|c|c|c|c|c|c|c|c|}
\hline \multirow[t]{2}{*}{ Study } & \multirow[t]{2}{*}{ Study design $(N)^{\mathrm{a}}$} & \multirow[t]{2}{*}{ Measuring instrument ${ }^{b}$} & \multicolumn{2}{|c|}{ Comprehensive care group ${ }^{c}$} & \multicolumn{2}{|l|}{ Usual care group } & \multirow[t]{2}{*}{$p$} \\
\hline & & & Baseline & Follow-up & Baseline & Follow-up & \\
\hline $\begin{array}{l}\text { Cognitive functioning } \\
\text { Burns et al. [66] }\end{array}$ & $\operatorname{RCT}(N=130)$ & MMSE & $24.6(3.6)$ & $25.8(3.2)$ & $24.5(3.1)$ & $24.7(3.8)$ & $\begin{array}{l}>0.05 \text {, for group difference } \\
<0.01 \text {, for time change } \\
>0.05 \text {, for interaction effect }\end{array}$ \\
\hline Chumbler et al. [79] & $\begin{array}{l}\text { Case control design in } \\
\text { which subjects } \\
\text { receiving } \\
\text { comprehensive care } \\
\text { were compared with } \\
\text { subjects from another } \\
\text { longitudinal study } \\
(N=226)\end{array}$ & $\begin{array}{l}\text { MMSE } \\
\text { FIM cognitive subscale }\end{array}$ & $\begin{array}{l}20.8(6.8) \\
29.2(5.2)\end{array}$ & $\begin{array}{l}25.8(4.7) \\
31.8(5.3)\end{array}$ & $\begin{array}{l}26.2(6.4) \\
31.3(6.8)\end{array}$ & $\begin{array}{l}28.2(6.4) \\
31.0(6.7)\end{array}$ & $\begin{array}{l}0.59 \text {, for group difference } \\
<0.0001 \text {, idem }\end{array}$ \\
\hline Duke et al. [55] & $\begin{array}{l}\text { Pretest-posttest design } \\
(N=107)\end{array}$ & MMSE & N.R. & N.R. & - & - & N.R. \\
\hline Mitton et al. [60] & $\begin{array}{l}\text { Pretest-posttest design } \\
(N=37)\end{array}$ & MMSE & N.R. & N.R. & - & - & 0.32 , for time change \\
\hline Saltvedt et al. [68,69] & $\mathrm{RCT}(N=254)$ & MMSE & $\sim 25.0$ (N.R.) & $\sim 25.0$ (N.R.) & $\sim 25.1$ (N.R.) & $\sim 24.9$ (N.R) & $>0.05$, for group difference \\
\hline $\begin{array}{l}\text { Depressive symptoms } \\
\text { Burns et al. [66] }\end{array}$ & $\mathrm{RCT}(N=130)$ & CES-D & $10.9(11.0)$ & $3.9(5.2)$ & $11.7(10.6)$ & $7.6(7.1)$ & $\begin{array}{l}<0.01 \text {, for group difference } \\
<0.001 \text {, for time change } \\
<0.05 \text {, for interaction effect }\end{array}$ \\
\hline Coleman et al. [50] & $\operatorname{RCT}(N=169)$ & CES-D & 11.4 (N.R.) & 14.8 (N.R.) & 15.9 (N.R.) & 12.4 (N.R.) & 0.19 , for group difference \\
\hline Leveille et al. [56] & $\operatorname{RCT}(N=201)$ & CES-D & $10.1(8.0)$ & N.R. & $8.7(7.3)$ & & 0.526 , for group difference \\
\hline Markle - Reid et al. [58] & $\operatorname{RCT}(N=288)$ & CES-D & $15.8(10.0)$ & $11.9(10.2)$ & $12.9(8.5)$ & $11.8(10.7)$ & 0.022 , for group difference \\
\hline Rubenstein et al. [61] & $\operatorname{RCT}(N=792)$ & GDS-15 & $5.0(3.6)$ & $3.9(3.2)$ & $5.2(3.7)$ & $3.4(3.4)$ & $>0.05$, for group difference \\
\hline $\begin{array}{l}\text { Saltvedt et al. [68,69] } \\
\text { Taylor et al. }[76]\end{array}$ & $\begin{array}{l}\operatorname{RCT}(N=254) \\
\operatorname{RCT}(N=169)\end{array}$ & $\begin{array}{l}\text { MADRS } \\
\text { BDI }\end{array}$ & N.R. & N.R. & N.R. & N.R. & $>0.05$, for group difference \\
\hline Taylor et al. [76] & $\operatorname{RCT}(N=169)$ & BDI & N.R. & N.R. & N.R. & N.R. & N.R. \\
\hline $\begin{array}{l}\text { Functional status } \\
\text { Burns et al. [66] }\end{array}$ & $\mathrm{RCT}(N=130)$ & Katz ADL & $0.3(0.8)$ & $0.2(0.7)$ & $0.5(1.1)$ & $0.4(1.0)$ & $\begin{array}{l}>0.05 \text {, for group difference } \\
<0.01 \text {, for time change } \\
>0.05 \text {, for interaction effect }\end{array}$ \\
\hline & & IADL & $11.6(5.4)$ & $11.9(6.2)$ & $10.9(4.1)$ & $12.7(6.1)$ & $\begin{array}{l}>0.05 \text {, for group difference } \\
<0.01 \text {, for change over time } \\
>0.05 \text { for interaction effect }\end{array}$ \\
\hline Chumbler et al. [79] & $\begin{array}{l}\text { Case control design in } \\
\text { which subjects } \\
\text { receiving } \\
\text { comprehensive care } \\
\text { were compared with } \\
\text { subjects from another } \\
\text { longitudinal study } \\
(N=226)\end{array}$ & $\begin{array}{l}\text { FIM motor subscale } \\
\text { IADL }\end{array}$ & $\begin{array}{l}85.3(21.9) \\
9.0(4.3)\end{array}$ & $\begin{array}{l}99.2(15.2) \\
11.4(3.1)\end{array}$ & $\begin{array}{l}73.9(14.2) \\
8.6(4.1)\end{array}$ & $\begin{array}{l}73.3(14.5) \\
8.3(4.2)\end{array}$ & $\begin{array}{l}<0.0001 \text {, for group difference } \\
<0.0001 \text {, idem }\end{array}$ \\
\hline \multicolumn{8}{|l|}{ Table 3 a (Continued) } \\
\hline \multirow[t]{2}{*}{ Study } & \multirow[t]{2}{*}{ Study design $(N)^{a}$} & \multirow[t]{2}{*}{ Measuring instrument ${ }^{b}$} & \multicolumn{2}{|c|}{ Comprehensive care group ${ }^{c}$} & \multicolumn{2}{|c|}{ Usual care group } & \multirow[t]{2}{*}{$p$} \\
\hline & & & Baseline & Follow-up & Baseline & Follow-up & \\
\hline Counsell et al. [51,52] & $\operatorname{cRCT}(N=951)$ & $\begin{array}{l}\text { AHEAD (ADL items) } \\
\text { AHEAD (IADL items) }\end{array}$ & $\begin{array}{l}1.6(3.1) \\
2.7(4.2)\end{array}$ & $\begin{array}{l}\text { N.R. } \\
\text { N.R. }\end{array}$ & $\begin{array}{l}1.3(2.6) \\
2.5(3.9)\end{array}$ & $\begin{array}{l}\text { N.R. } \\
\text { N.R. }\end{array}$ & $\begin{array}{l}0.37 \text {, for group difference } \\
0.77 \text {, idem }\end{array}$ \\
\hline $\begin{array}{l}\text { Douglas et al. [73] } \\
\text { Leveille et al. [56] }\end{array}$ & $\begin{array}{l}\operatorname{RCT}(N=334) \\
\operatorname{RCT}(N=201)\end{array}$ & $\begin{array}{l}\text { OASIS } \\
\text { HAQ }\end{array}$ & $\begin{array}{l}\text { N.R. } \\
0.24(0.32)\end{array}$ & $\begin{array}{l}24.5(11.6) \\
\text { N.R. }\end{array}$ & $\begin{array}{l}\text { N.R. } \\
0.23(0.34)\end{array}$ & $\begin{array}{l}22.5(13.5) \\
\text { N.R. }\end{array}$ & $\begin{array}{l}0.33 \text {, for group difference } \\
0.014 \text {, for group difference }\end{array}$ \\
\hline Mitton et al. [60] & $\begin{array}{l}\text { Pretest-posttest design } \\
(N=37)\end{array}$ & Barthel index & N.R. & N.R. & $-29(0.04)$ & - & \\
\hline Naylor et al. [74] & $\mathrm{RCT}(N=239)$ & ESDS & $3.3(1.1)$ & $3.1(1.5)$ & $3.3(1.1)$ & $2.9(1.6)$ & $>0.10$, for group difference \\
\hline Rubenstein et al. [61] & $\mathrm{RCT}(N=792)$ & $\begin{array}{l}\text { FSQ (ADL items) } \\
\text { FSQ (IADL items) }\end{array}$ & $\begin{array}{l}84.1(19.6) \\
53.9(26.3)\end{array}$ & $\begin{array}{l}82.4(22.1) \\
56.5(32.9)\end{array}$ & $\begin{array}{l}82.8(20.4) \\
53.4(28.6)\end{array}$ & $\begin{array}{l}85.2(20.6) \\
58.2(31.7)\end{array}$ & $\begin{array}{l}>0.05 \text {, for group difference } \\
\text { Idem }\end{array}$ \\
\hline Saltvedt et al. $[68,69]$ & $\mathrm{RCT}(N=254)$ & $\begin{array}{l}\text { Barthel index } \\
\text { IADL. }\end{array}$ & $\begin{array}{l}\sim 15.5 \text { (N.R) } \\
\sim 4.0 \text { (N.R.) }\end{array}$ & $\begin{array}{l}\sim 15.0 \text { (N.R.) } \\
\sim 4.2 \text { (N.R.) }\end{array}$ & $\begin{array}{l}\sim 16.0(\mathrm{~N} . \mathrm{R}) \\
\sim 4.2 \text { (N.R.) }\end{array}$ & $\begin{array}{l}\sim 15.0 \text { (N.R.) } \\
4.1 \text { (N.R.) }\end{array}$ & $\begin{array}{l}>0.05 \text {, for group difference } \\
>0.05 \text {, idem }\end{array}$ \\
\hline \multirow{3}{*}{$\begin{array}{l}\text { Health behavior } \\
\text { Elzen et al. [77] }\end{array}$} & & & & & & & \\
\hline & $\mathrm{RCT}(\mathrm{N}=144)$ & $\begin{array}{l}\text { Exercise (Lorig) } \\
\text { Cognitive symptom }\end{array}$ & $\begin{array}{l}\text { N.R. } \\
\text { N.R. }\end{array}$ & $\begin{array}{l}\text { N.R. } \\
\text { N.R. }\end{array}$ & $\begin{array}{l}\text { N.R. } \\
\text { N.R. }\end{array}$ & $\begin{array}{l}\text { N.R. } \\
\text { N.R. }\end{array}$ & $\begin{array}{l}0.47 \text {, for group difference } \\
0.14 \text {, idem }\end{array}$ \\
\hline & & $\begin{array}{l}\text { Communication with } \\
\text { physician (Lorig) }\end{array}$ & N.R. & N.R. & N.R. & N.R. & 0.48, idem \\
\hline \multirow[t]{2}{*}{ Kobb et al. [40] } & $\mathrm{CCT}(N=1401)$ & $\begin{array}{l}\text { Immunization } \\
\text { compliance }\end{array}$ & N.R. & N.R. & N.R. & N.R. & Not tested for significance \\
\hline & & Medication compliance & N.R. & N.R. & N.R. & N.R. & Not tested for significance \\
\hline Krause et al. [64] & $\begin{array}{l}\text { Pretest-posttest } \\
\text { design }(N=39)\end{array}$ & $\begin{array}{l}\text { PPCQ (exercise) } \\
\text { PPCQ (healthy eating) }\end{array}$ & $\begin{array}{l}2.49(1.49) \\
3.69(1.15)\end{array}$ & $\begin{array}{l}3.64(1.29) \\
4.08(1.09)\end{array}$ & - & - & $\begin{array}{l}<0.001 \text {, for time change } \\
0.030 \text {, idem }\end{array}$ \\
\hline Leveille et al. [56] & $\mathrm{RCT}(N=201)$ & PACE & 5.60 (N.R.) & N.R. & 4.97 (N.R.) & N.R. & 0.028 , for group difference \\
\hline \multirow[t]{4}{*}{ Rose et al. [78] } & \multirow[t]{4}{*}{$\begin{array}{l}\text { Pretest-posttest design } \\
(N=175)\end{array}$} & $\begin{array}{l}\text { Stretching and } \\
\text { strengthening (Lorig) }\end{array}$ & $1.07(1.2)$ & $1.42(1.2)$ & - & - & 0.03 , for time change \\
\hline & & Aerobic exercise (Lorig) & $0.68(0.9)$ & $0.64(0.7)$ & - & - & $>0.05$, idem \\
\hline & & $\begin{array}{l}\text { Cognitive symptom } \\
\text { management (Lorig) }\end{array}$ & $1.48(1.0)$ & $1.71(1.0)$ & - & - & 0.06, idem \\
\hline & & $\begin{array}{l}\text { Communication with } \\
\text { physician (Lorig) }\end{array}$ & $2.49(1.4)$ & $2.80(1.0)$ & - & - & 0.03, idem \\
\hline & & & & & & & \\
\hline $\begin{array}{l}\text { Brand et al. [65] } \\
\text { Coleman et al. [50] }\end{array}$ & $\begin{array}{l}\mathrm{CCT}(N=166) \\
\mathrm{RCT}(N=169)\end{array}$ & $\begin{array}{l}\text { AQoL } \\
\text { SF-36, PCS }\end{array}$ & $\begin{array}{l}8.7(0.57) \\
47.7 \text { (N.R.) }\end{array}$ & $\begin{array}{l}\text { N.R. } \\
37.5 \text { (N.R) }\end{array}$ & $\begin{array}{l}9.2(0.48) \\
43.8 \text { (N.R.) }\end{array}$ & $\begin{array}{l}\text { N.R. } \\
37.5 \text { (N.R.) }\end{array}$ & $\begin{array}{l}>0.05 \text {, group difference } \\
0.97 \text {, for group difference }\end{array}$ \\
\hline Counsell et al. [51,52] & $\operatorname{CRCT}(N=951)$ & $\begin{array}{l}\text { SF-36, PCS } \\
\text { SF-36, MCS }\end{array}$ & $\begin{array}{l}35.8(10.8) \\
51.0(10.2)\end{array}$ & $\begin{array}{l}\text { N.R. } \\
\text { N.R. }\end{array}$ & $\begin{array}{l}36.5(11.2) \\
51.7(10.4)\end{array}$ & $\begin{array}{l}\text { N.R. } \\
\text { N.R. }\end{array}$ & $\begin{array}{l}0.38 \text {, for group difference } \\
<0.001 \text {, idem }\end{array}$ \\
\hline Courtney et al. [67] & $\mathrm{RCT}(\mathrm{N}=128)$ & $\begin{array}{l}\text { SF-12, PCS } \\
\text { SF-12, MCS }\end{array}$ & $\begin{array}{l}32.6(10.3) \\
46.2(12.7)\end{array}$ & $\begin{array}{l}43.8(9.4) \\
59.4(5.1)\end{array}$ & $\begin{array}{l}34.5(10.6) \\
46.4(10.6)\end{array}$ & $\begin{array}{l}26.0(9.9) \\
48.3(7.7)\end{array}$ & $\begin{array}{l}<0.001 \\
<0.001\end{array}$ \\
\hline Douglas et al. [73] & $\operatorname{RCT}(N=334)$ & $\begin{array}{l}\text { SF-8, PCS } \\
\text { SF-8, MCS }\end{array}$ & $\begin{array}{l}-44.0 \\
\text { N.R. }\end{array}$ & $\begin{array}{l}\sim 41.0 \\
\text { N.R. }\end{array}$ & $\begin{array}{l}\sim 44.0 \\
\text { N.R. }\end{array}$ & $\begin{array}{l}\sim 43.0 \\
\text { N.R. }\end{array}$ & $\begin{array}{l}0.12 \text {, for group difference } \\
0.22 \text {, idem }\end{array}$ \\
\hline Duke et al. [55] & $\begin{array}{l}\text { Pretest-posttest design } \\
(N=107)\end{array}$ & MGDS & N.R. & N.R. & - & - & N.R. \\
\hline
\end{tabular}


Bruin, S.R. de, Versnel, N., Lemmens, L.C., Molema, C.C.M., Schellevis, F.G., Nijpels, G., Baan C.A. Comprehensive care programs for patients with multiple chronic conditions: a systematic literature review. Health Policy: 2012, 107(2-3), 108-145

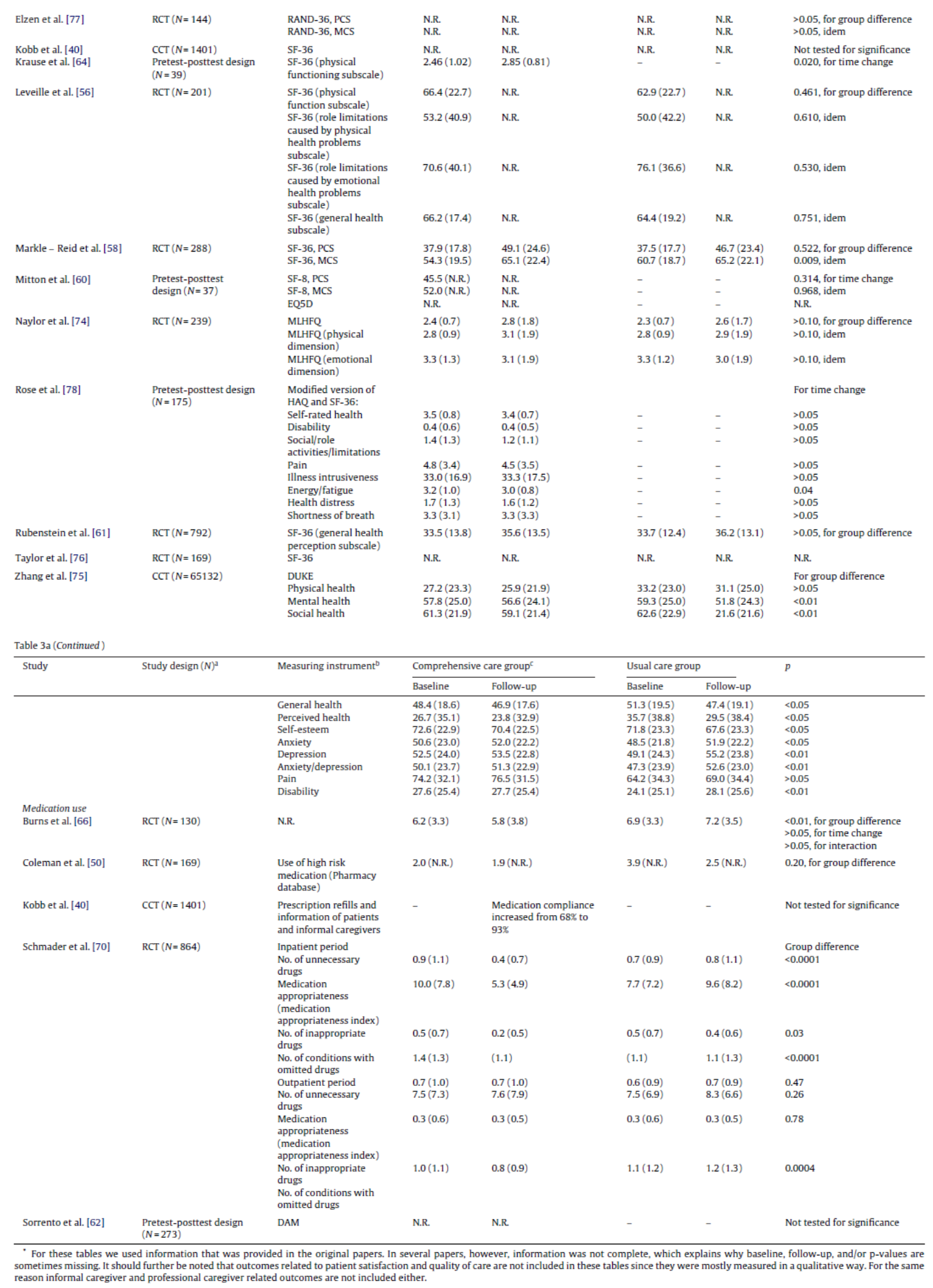


Bruin, S.R. de, Versnel, N., Lemmens, L.C., Molema, C.C.M., Schellevis, F.G., Nijpels, G., Baan C.A. Comprehensive care programs for patients with multiple chronic conditions: a systematic literature review. Health Policy: 2012, 107(2-3), 108-145

Table 3b
Clinical patient outcomes of studies evaluating impact of comprehensive care programs for multimorbid patients.

\begin{tabular}{|c|c|c|c|c|c|c|c|}
\hline \multirow[t]{2}{*}{ Study } & \multirow[t]{2}{*}{ Study design $(N)^{2}$} & \multirow[t]{2}{*}{ Measuring instrument $t^{b}$} & \multicolumn{2}{|c|}{$\begin{array}{l}\text { Comprehensive care } \\
\text { group }{ }^{\epsilon}\end{array}$} & \multicolumn{2}{|c|}{ Usual care groupf } & \multirow[t]{2}{*}{$p$} \\
\hline & & & $\begin{array}{l}\text { Baseline } \\
N \text { or } \%\end{array}$ & $\begin{array}{l}\text { Follow-up } \\
N \text { or } \%\end{array}$ & $\begin{array}{l}\text { Baseline } \\
N \text { or } X\end{array}$ & $\begin{array}{l}\text { Follow-up } \\
N \text { or } \mathbb{R}\end{array}$ & \\
\hline $\begin{array}{l}\text { Medication use } \\
\text { Tibaldi et al. [71] }\end{array}$ & $\operatorname{RCT}(N-109)$ & $\begin{array}{l}\text { Number of patients } \\
\text { using antipsychotic } \\
\text { drugs }\end{array}$ & $N=26$ & $N-6$ & $N=17$ & $N=13$ & $\begin{array}{l}0.001 \text {, for group } \\
\text { difference }\end{array}$ \\
\hline $\begin{array}{l}\text { Mortality } \\
\text { Counsell et al. [51,52] }\end{array}$ & $\operatorname{cRCT}(N-951)$ & Number of deaths & - & $N=33$ & - & $N=37$ & $\begin{array}{l}0.64 \text {, for group } \\
\text { difference }\end{array}$ \\
\hline Dorr et al. [53,54] & $\begin{array}{l}\mathrm{CCT}(N-3432 \text {, of } \\
\text { whom } 1671 \text { had } \\
\text { complex illness } \\
\text { including diabetes) }\end{array}$ & $\begin{array}{l}\text { Rate of deaths } \\
\text { All pattents wth } \\
\text { complex Iliness } \\
\text { Patlents with complex } \\
\text { tllness tncluding } \\
\text { diabetes }\end{array}$ & - & $\begin{array}{l}13.1 \% \\
\text { N.R. }\end{array}$ & - & $\begin{array}{l}16.68 \\
\text { N.R. }\end{array}$ & $\begin{array}{l}0.07 \text {, for group } \\
\text { difference } \\
0.03 \text {, idem }\end{array}$ \\
\hline Douglas et al. [73] & $\mathrm{RCT}(\mathrm{N}-334)$ & Number of deaths & - & N.R. & - & N.R. & $>0,05$, for group \\
\hline Naylor et al. [74] & $\mathrm{RCT}(\mathrm{N}-239)$ & Number of deaths & - & $N-11$ & - & $N=13$ & $\begin{array}{l}0.830 \text {, for group } \\
\text { difference }\end{array}$ \\
\hline Saltvedt et al. [68,69] & $\mathrm{RCT}(\mathrm{N}-254)$ & Number of deaths & - & $N=35$ & - & $N=43$ & $\begin{array}{l}>0.05 \text {, for group } \\
\text { difference }\end{array}$ \\
\hline Tibaldi et al. [71] & $\operatorname{RCT}(N-109)$ & Number of deaths & N.R. & N.R. & N.R. & N.R. & $\begin{array}{l}>0.05 \text {, for group } \\
\text { difference }\end{array}$ \\
\hline
\end{tabular}

a CCT - controlled clinical trial; cRCT- cluster-randomized controlled trial; RCT- randomized controlled trial.

b ADL-Activities of Daily Living: AHEAD-Assets and Health Dynamics of the Oldest-Old: AQoL-Assessment of Quality of Life Instrument; BDI- Beck Depression Inventory: CES-D-Centre for Epidemiologic Studies Depression Scale; DAM-Drug Appropriateness Measure; DUKE- Duke Health Profile; EQSD-A measure of health status of the EuroQol Group; ESDS- Enforces Social Dependency Scale; FIM-Functional Independence Measure: FSQ-Functional Status Questionnaire; GDS-Geriatric Depression Scale; HAQ- Health Assessment Questionnaire; LADL- instrumental activities of daily living: MADRS-Montgomery Asberg Depression Rating Scale; MCS-Mental Component Scale; MGDS-Modified Geriatric Depression Scale: MLHFQ-Minnesota Living with Heart Failure Questionnaire; MMSE-Mini Mental State Examination; N.R.- not reported OASIS-Outcomes and Assessment Information Set; PACE- Physician-based Assessment and Counseling for Exercise scoring form; PCS- Physical Component Scale PPCQ- Perception of Personal Control Questionnaire; SF-8, SF-12, SF-36-Medical Outcomes 8-item, 12-item, and 36-item short-form.

C.R.-not reported.

- For these tables we used information that was provided in the original papers. In several papers, however, information was not complete, which explains why baseline, follow-up, and/or p-values are sometimes missing. It should further be noted that outcomes related to patient satisfaction and quality of care are not included in these tables since they were mostly measured in a qualitative way. For the same reason informal caregiver and professional caregiver are not included in these tables since they witcomes are not included either. 